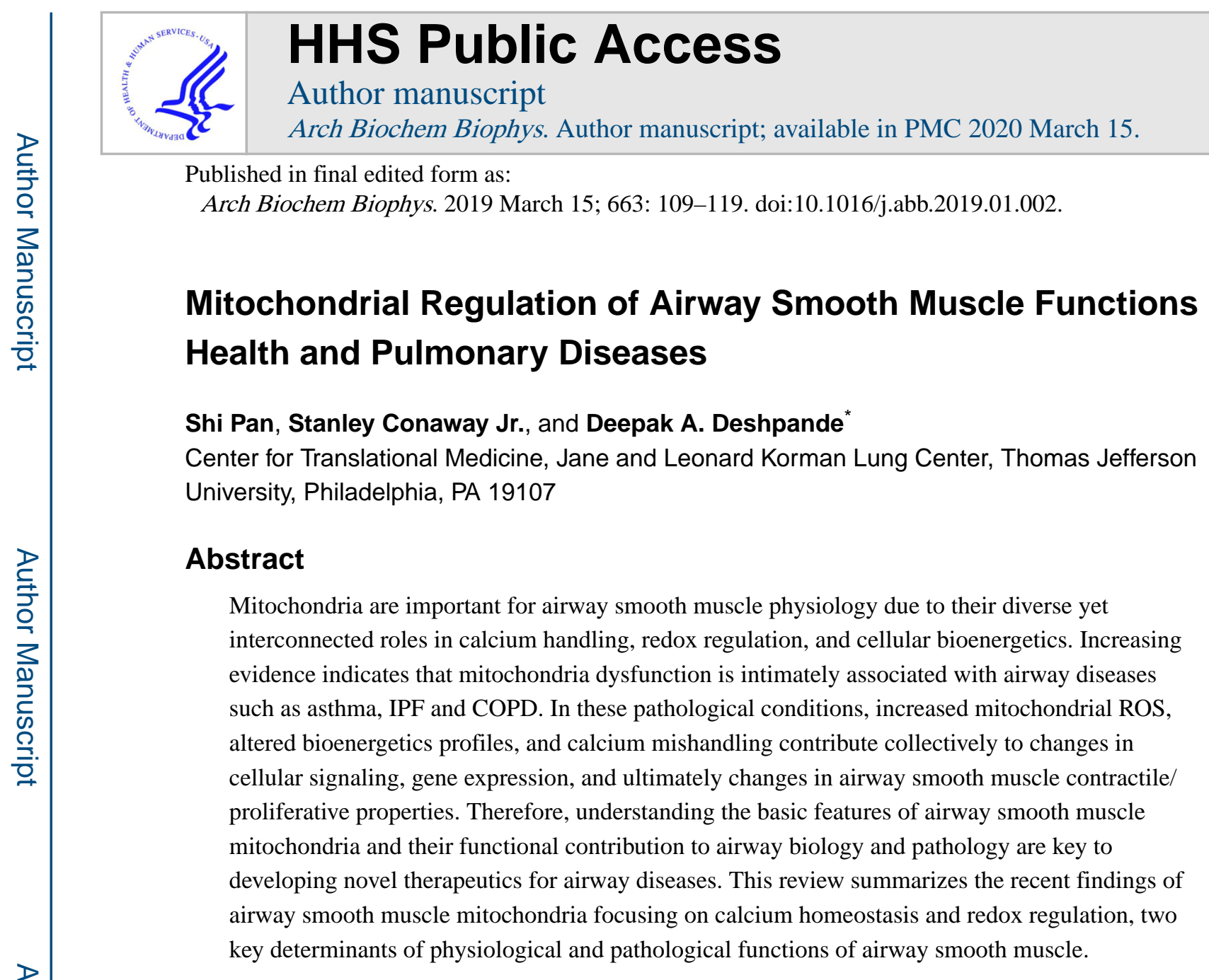

\title{
Keywords
}

Airway smooth muscle; mitochondria; calcium; contraction; proliferation

\begin{abstract}
Airway smooth muscle (ASM) resides in the trachea and bronchial tree up to the terminal bronchioles. It is the primary determinant of the airway pathophysiology via its regulation of diameter of the bronchi and bronchomotor tone. In addition to contractile function, ASM cells secrete extracellular matrix, cytokines/chemokines and undergo excessive proliferation, most notably under airway pathologies. To perform diverse functions, ASM transitions between a "mature" contractile phenotype and a proliferative/ synthetic phenotype characterized by a tendency to grow and/or synthesize extracellular matrix and other biologically active proteins. ASM plasticity plays a central role in both lung development and in disease conditions such as asthma, chronic bronchitis and emphysema [1,2]. The modulation of this phenotypic switch is accomplished by a complex, coordinated interaction among external stimuli such as growth factors, extracellular matrix and ASM cells with
\end{abstract}

\footnotetext{
*Address for Correspondence, Deepak A. Deshpande, Ph.D., Associate Professor, Center for Translational Medicine, Jefferson Alumni Hall, Rm 5431020 Locust Street, Philadelphia, PA 19107, Ph: 215-955-3305, deepak.deshpande @ jefferson.edu.

Publisher's Disclaimer: This is a PDF file of an unedited manuscript that has been accepted for publication. As a service to our customers we are providing this early version of the manuscript. The manuscript will undergo copyediting, typesetting, and review of the resulting proof before it is published in its final citable form. Please note that during the production process errors may be discovered which could affect the content, and all legal disclaimers that apply to the journal pertain.
} 
external stimuli, eliciting a network of intracellular signaling cascades in ASM cells leading to transcriptional activation and protein translation of phenotype-specific genes. Each of the functions of ASM involves smooth muscle contractile proteins, cytoskeleton, intermediate filaments and organelles such as the sarcoplasmic (endoplasmic) reticulum and mitochondria. In this review, we discuss recent findings on ASM mitochondria focusing on their role in the most important aspects of ASM physiology and pathology, such as ASM contractility and proliferation/remodeling.

In recent years, mitochondria have been increasingly recognized as important organelles in ASM pathophysiology and homeostasis due to their indispensable roles in cellular energy production, redox regulation and calcium homeostasis. The dominant role of mitochondria is to produce the cellular energy in the form of ATP that is required for contraction, relaxation and synthetic functions of ASM. This is achieved via oxidative phosphorylation (OXPHOS) of glucose, pyruvate, and NAD and is known as aerobic respiration (Figure 1). Calciumdependent dehydrogenases in the inner mitochondrial matrix reduce $\mathrm{NAD}^{+}$and FADH to $\mathrm{NADH}$ and $\mathrm{FADH}_{2}$ in response to increases in mitochondrial calcium $\left(\left[\mathrm{Ca}^{2+}\right]_{\mathrm{m}}\right)[3,4]$. The redox energy from $\mathrm{NADH}$ and $\mathrm{FADH}_{2}$ is transferred to oxygen $\left(\mathrm{O}_{2}\right)$ via the electron transport chain (ETC). Following the acceptance of an electron, each complex in the ETC pumps protons $\left(\mathrm{H}^{+}\right)$from the matrix into the intermembrane space. At the end of the ETC in complex IV, the two donated electrons are used to convert $\mathrm{O}_{2}$ into $\mathrm{H}_{2} \mathrm{O}$ [5-7]. The increase in the $\mathrm{H}^{+}$gradient in the intermembrane space, also known as the proton motive force, drives the influx of $\mathrm{H}^{+}$back into the matrix through the $\mathrm{F}_{1} \mathrm{~F}_{0}$ ATP synthase proton pump. $\mathrm{F}_{1} \mathrm{~F}_{0}$ ATP synthase uses the proton motive force to generate ATP from ADP and inorganic phosphate [5-7]. Newly synthesized ATP is transported into the intermembrane space in exchange for ADP through the adenine nucleotide translocator, where it is then transported across the outer mitochondrial membrane through the voltage-dependent anion channel (VDAC) to the cytosol [8]. Therefore, calcium concentration in the mitochondria is an important regulator of the ATP generating function of mitochondria. During the electron transfer, a small percentage of electrons leak from the ETC and reduce oxygen leading to the production of superoxide, a major form of mitochondrial reactive oxygen species (ROS). Although physiological levels of ROS can function as a second messenger for cell signaling, increased ROS production is detrimental causing DNA and protein damage, and ultimately cell death.

In addition to serving as a powerhouse of ASM cells and source of ROS, mitochondria also contribute to cellular calcium homeostasis by their ability to temporally store calcium. This ability of mitochondria makes them the temporal storage unit of cellular calcium besides the sarcoplasmic reticulum (SR) or endoplasmic reticulum (ER), which is a major calcium store inside of ASM cells. There is an interplay between the SR/ER and mitochondria with regard to calcium regulation in part due to anatomic juxtaposition. Increase in cytosolic calcium mitochondrial calcium uniporter (MCU) that resides in the inner mitochondrial membrane is responsible for the uptake of calcium into mitochondria matrix, while the release of calcium from mitochondria back to the cytosol occurs via a mitochondrial sodium-calcium exchanger (NCX) $[9,10]$. Therefore, mitochondria function as the calcium buffering system of the cells by rapidly taking up and releasing calcium. 
Taken together, the functional role of mitochondria in ATP synthesis, ROS generation and regulation of calcium homeostasis support the hypothesis that healthy mitochondria are indispensable for ASM physiology. Mitochondrial dysfunctions associated with decreased ATP, increased ROS and calcium mishandling contribute directly to pulmonary aging and lung diseases including pulmonary fibrosis (IPF), asthma and chronic obstructive pulmonary disease (COPD) [11-13].

\section{Mitochondria in the regulation of $\mathrm{Ca}^{2+}$ dynamics and contractility in ASM}

Calcium is a master regulator of contractility of ASM. As a secondary messenger, calcium transduces signals from the cell surface to enzymatic components inside of the cell. Therefore, $\mathrm{Ca}^{2+}$ is intimately involved in "excitation-contraction coupling" of ASM.

In a resting condition, ASM cells maintain relatively low intracellular $\mathrm{Ca}^{2+}$ concentration. Upon exposure of ASM cells to contractile agonists, the activation of membrane receptors such as G-protein-coupled receptors (GPCRs) triggers a signaling cascade followed by a rapid rise in intracellular calcium $\left(\left[\mathrm{Ca}^{2+}\right]_{\mathrm{i}}\right)$. In ASM cells, a rise in intracellular $\mathrm{Ca}^{2+}$ concentration activates downstream contractile signaling. Calcium binds to calmodulin and the Ca-CaM complex activates calmodulin kinase, which in turn activates myosin light chain kinase (MLCK). Phosphorylation of myosin light chain by MLCK is a critical first step in the initiation of actin-myosin cross-bridge cycling and contraction. Among GPCRs, Gqcoupled receptors in ASM are of particular interest due to their prominent role in promoting ASM contraction (Figure 2).

Activation of contractile agonist receptors coupled to a Gq-type of G protein activates the $\beta$ isoform of phospholipase C (PLC- $\beta$ ), which produces two second messengers, inositol 1.4.5-triphosphate $\left(\mathrm{IP}_{3}\right)$ and 1,2-diacylglycerol (DAG), via hydrolysis of phosphatidylinositol 4,5- bisphosphate ( $\left.\mathrm{PIP}_{2}\right)$. $\mathrm{IP}_{3}$ diffuses through the cytosol and binds to its specific receptor $\left(\mathrm{IP}_{3} \mathrm{R}\right)$ located on the $\mathrm{SR}$, thereby mobilizing the $\mathrm{IP}_{3}$-sensitive pool of intracellularly stored $\mathrm{Ca}^{2+}$, whereas DAG activates protein kinase $\mathrm{C}$ (PKC), which affects the sensitivity of the contractile apparatus to $\mathrm{Ca}^{2+}$. However, recent identification of receptors such as Type II taste receptors (TAS2Rs), proton-sensing receptor (OGR-1) and gamma-aminobutyric acid (GABA) receptors on ASM cells has renewed interest in establishing the causal relationship between calcium elevation and contraction in ASM. Paradoxically, elevation of intracellular calcium by agonists belonging to TAS2Rs, OGR-1 and GABARs leads to relaxation of ASM cells [14-16]. In general, these functional diversities of calcium in ASM suggest signaling and functional compartmentalization. What role different compartments such as mitochondria play in calcium signaling compartmentalization in ASM cells needs further investigation.

The intracellular calcium response elicited by the contractile agonists is biphasic. The initial phase is a rapid and transient rise of calcium concentration from the baseline levels, which is responsible for ASM tension development. The rapid rise in ASM $\left[\mathrm{Ca}^{2+}\right]_{i}$ then declines to a lower, sustained steady-state concentration slightly above the baseline level, which is associated with tension maintenance [17-20]. The initial calcium spike is due to a release of calcium from intracellular stores, the SR, induced by $\mathrm{IP}_{3}$, while the sustained phase of the 
response originates from the calcium influx from the extracellular space [18, 19, 21-23].

The initial increase in calcium is coupled to calcium uptake into mitochondria and is necessary in order to drive ATP synthesis [24-27].

As a major player in the regulation of intracellular calcium, mitochondria are strategically localized either in close proximity of the $\mathrm{IP}_{3} \mathrm{R}$ calcium release sites of the $\mathrm{SR}$, or the calcium influx channels on the plasma membrane $[25,28]$. $\mathrm{IP}_{3}$-mediated rise of intracellular calcium results in large, rapid increases in $\left[\mathrm{Ca}^{2+}\right]_{\mathrm{m}}$ in parallel with cytosolic calcium $\left(\left[\mathrm{Ca}^{2+}\right]_{\text {cyto }}\right)$ rises evoked by the contractile agonist [25]. Other mechanisms of elevating intracellular calcium such as calcium influx from the extracellular space has much less influence on $\left[\mathrm{Ca}^{2+}\right]_{\mathrm{m}}$ compared to the calcium rise mediated by $\mathrm{IP}_{3}[25]$. Furthermore, caffeine-induced calcium release from the SR (mediated primarily via ryanodine-sensitive SR stores) increases $\left[\mathrm{Ca}^{2+}\right]_{\mathrm{m}}[29]$ suggesting possible involvement of the ryanodine receptor in the regulation of mitochondrial calcium.Interestingly, kinetics analysis demonstrated that the increase in $\left[\mathrm{Ca}^{2+}\right]_{\mathrm{m}}$ coincides with the increase in $\left[\mathrm{Ca}^{2+}\right]_{\mathrm{i}}$ and remains elevated after $\left[\mathrm{Ca}^{2+}\right]_{\mathrm{i}}$ returns to resting levels. Earlier studies in various types of smooth muscle showed that agonist-induced $\left[\mathrm{Ca}^{2+}\right]_{\mathrm{i}}$ increase is almost fully inhibited when mitochondrial calcium uptake is prevented, suggesting an indispensable role for mitochondria in the regulation of intracellular calcium signaling [30-33]. The direct evidence for the role of mitochondria in calcium handling comes from studies using protonophore carbonyl cyanide $p \square$ (trifluoromethoxy) phenylhydrazone (FCCP), which is known to depolarize mitochondria. FCCP pretreatment attenuates caffeine-induced increase in $\left[\mathrm{Ca}^{2+}\right]_{\mathrm{m}}$ and increases the half $\square$ time for recovery of $\left[\mathrm{Ca}^{2+}\right]_{\mathrm{i}}$ to resting values [29]. More direct evidence was provided by using a system in which calcium release was evoked by photolysis of caged $\mathrm{IP}_{3}$ instead of agonist stimulation. $\mathrm{IP}_{3}$-induced calcium release was significantly reduced by inhibiting mitochondrial calcium uptake under conditions where ATP levels, $\mathrm{PH}$, and plasma membrane potential were all controlled [30, 34-36]. Collectively, multiple lines of evidence suggest the critical role of mitochondria in calcium regulation in smooth muscle cells.

It has become clear that the mitochondrial calcium uptake is not simply a passive process. Mitochondria contain their own specific calcium transport systems. The uptake of calcium into the mitochondria is mediated by the $\mathrm{MCU}$, the molecular identity of which has recently been unraveled. Calcium release from mitochondria is mediated by either the $\mathrm{Na}^{+} / \mathrm{Ca}^{2+}$ or $\mathrm{H}$ $+/ \mathrm{Ca}^{2+}$ exchanger [37-41]. Recent studies suggest that the MCU has a higher threshold of activation in response to $\mathrm{Ca}^{2+}$ higher than $10 \mu \mathrm{M}$, whereas the $\left[\mathrm{Ca}^{2+}\right]_{\text {cyto }}$ in response to agonist stimulation is around $2 \mu \mathrm{M}$ [42]. One logical explanation is that MCUs are in close proximity to $\mathrm{IP}_{3}$ gated channels on the $\mathrm{SR}$, where $\left[\mathrm{Ca}^{2+}\right]_{\text {cyto }}$ is high enough to be sensed by mitochondria. Perhaps this geographical orientation of mitochondria in proximity to calcium release channels on the SR can be called calcium "microdomains" or hotspots [25, 4 3-47]. In this theory, mitochondria-SR communications are strictly dependent on the spatial localization of mitochondria within the cells. Spatial and temporal organization of mitochondria in microdomains and the molecular mechanisms by which mitochondria sense the high concentrations of calcium remain to be determined in ASM cells.

Whether mitochondria act purely as a calcium sink or as a calcium relay mechanism is still not clear. Recent studies in ASM cells determining the effect of $\left[\mathrm{Ca}^{2+}\right]_{i}$ clearance by either 
the sarcoplasmic/endoplasmic reticulum calcium ATPase (SERCA) or mitochondria further support an important role for mitochondria in calcium handling [48]. The mathematical models of calcium regulation in ASM indicate that calcium is first sequestrated by mitochondria before it is pumped back into the SR. Furthermore, the mitochondria uncoupler, carbonyl cyanide 4-(trifluoromethoxy) phenylhydrazone, but not SERCA inhibitor cyclopiazonic acid, significantly affected calcium decay after calcium release from the SR [48]. Taken together, by localizing to the calcium release site of the SR and rapidly taking up calcium, mitochondria could potentially modulate the rate of calcium rise as well as the magnitude of the calcium spike in response to a contractile agonist. On the other hand, the release of calcium from mitochondria back to the cytosol during the decay phase could delay the recovery of cytosolic calcium to baseline levels [49-53]. Therefore, mitochondrial calcium handling could contribute not only to the local calcium buffering but also to propagating and synchronizing calcium signals in ASM cells.

In ASM cells, acetylcholine (ACh)-induced contractile response is associated with regenerative and propagating $\mathrm{Ca}^{2+}$ oscillations [54]. The rise and sustainment of $\mathrm{ACh}$ induced $\mathrm{Ca}^{2+}$-oscillations involving $\mathrm{IP}_{3}$-induced $\mathrm{Ca}^{2+}$ release were initially observed in fluo3-loaded porcine ASM cells $[55,56]$. Real-time spatial and temporal confocal imaging analysis indicated that within a small region of the cell, ACh-induced calcium oscillations are biphasic and are propagating throughout the cells. The oscillations originate from either one end or in the middle of the cell, and propagate to the other or both ends of the cell. Increases in Ach concentration increase frequency and propagation velocity of calcium oscillations without affecting the peaks [54] In contrast, the global spatial and temporal integration of the regional oscillation responses indicate an Ach concentration-dependent increase in both peak and mean cellular calcium concentrations. This pattern of calcium elevation in ASM cells involves the coordinated actions of calcium influx from the extracellular space via plasma membrane ion channels and release of calcium from the intracellular calcium store. What role, if any, mitochondria have in the regulation of calcium oscillations in ASM cells is not known. Previous studies indicate that initiation of calcium oscillations by Ach requires activation of the $\mathrm{IP}_{3} \mathrm{Rs}$ in the SR [57]. The increase in $\left[\mathrm{Ca}^{2+}\right]_{\mathrm{i}}$ promotes the binding of $\mathrm{Ca}^{2+}$ to the $\mathrm{IP}_{3} \mathrm{Rs}$. This enhances the open probability of $\mathrm{IP}_{3} \mathrm{Rs}$ leading to a continuous rise of the $\left[\mathrm{Ca}^{2+}\right]_{i}$, which will stimulate neighboring $\mathrm{IP}_{3} \mathrm{Rs}$ and further propagate a $\mathrm{Ca}^{2+}$ wave. Although refilling the $\mathrm{SR}$ with $\mathrm{Ca}^{2+}$ reestablishes the $\mathrm{Ca}^{2+}$ driving force, the SR $\left[\mathrm{Ca}^{2+}\right]$ may also be critical for the regulation of the SR release channel. When $\mathrm{Ca}^{2+}$ binds to a second site on the $\mathrm{IP}_{3} \mathrm{Rs}$, the additional binding of calcium reduces open probability of calcium release channels on SR. The localized decrease in $\left[\mathrm{Ca}^{2+}\right]$ of the $\mathrm{SR}$ and decreased open probability together terminate $\mathrm{Ca}^{2+}$ release from the SR.

While $\mathrm{IP}_{3}$-based $\mathrm{Ca}^{2+}$ oscillations require an $\mathrm{IP}_{3}$-induced $\mathrm{Ca}^{2+}$ release pathway, caffeineinduced $\mathrm{Ca}^{2+}$ release involves a mechanism independent of the $\mathrm{IP}_{3} \mathrm{Rs}[55,56]$. ACh-induced repetitive, propagating $\mathrm{Ca}^{2+}$ oscillations in isolated porcine tracheal SMCs were attenuated by ryanodine and caffeine [58] suggesting the involvement of ryanodine receptors (RyRs) in calcium oscillations. $\mathrm{IP}_{3}$ appears to be indispensable in the initiation of the $\mathrm{Ca}^{2+}$ oscillations. However, $\mathrm{IP}_{3}$ alone could not maintain $\mathrm{Ca}^{2+}$ oscillations. The maintenance of the $\mathrm{Ca}^{2+}$ oscillations requires the RyRs [58] and this involves activation of RyRs via a calciuminduced calcium release (CICR) mechanism [59]. Ryanodine pretreatment not only inhibited 
ACh-induced $\mathrm{Ca}^{2+}$ oscillations in muscle bundles from porcine or human airways, but also attenuated carbachol-induced contraction of mouse tracheal rings [60-62] suggesting the functional role of RyRs in the regulation of ASM contraction. Similar results were found using other less specific inhibitors of the RyR, such as procaine and tetracaine. Although in other cell types, $\mathrm{Ca}^{2+}$ oscillations are thought to occur via the $\mathrm{IP}_{3} \mathrm{R}$, in ASM cells, both $\mathrm{IP}_{3} \mathrm{R}$ and RyRs appear to play role in the regulation of $\mathrm{Ca}^{2+}$ oscillations. Additionally, in ASM cells, NAD metabolites such as cyclic ADP-ribose (cADPR) and nicotinic acid dinucleotide phosphate (NAADP) are known to regulate calcium release from the SR [63].

Although mitochondria can buffer calcium, it is puzzling that the mitochondrial calcium uptake fails to decrease cytosolic calcium during agonist-induced calcium oscillations [64, $25,65]$. The possible explanation is that calcium taken up by mitochondria may limit the chance of negative feedback regulation, which prevents the accumulation of high enough levels of local calcium or locations that would inhibit the open probabilities of $\mathrm{IP}_{3} R$. Nevertheless, mitochondria have the capability to modulate the activity of intracellular calcium release channel and store-operated, calcium influx channels [66, 67]. In colonic smooth muscle cells, inhibition of mitochondrial calcium uptake but not efflux impeded $\mathrm{IP}_{3} \mathrm{R}$ sensitive calcium release [68]. It is not clear whether mitochondria play a role in the regulation of calcium homeostasis mechanisms involving CICR or via NAD metabolites in ASM cells.

In order to sustain agonist-induced contraction of ASM, influx of extracellular $\mathrm{Ca}^{2+}$ is required. $\mathrm{Ca}^{2+}$ oscillations arise from intracellular stores and are sustained by calcium influx from the extracellular space [69]. Calcium influx can occur through a variety of mechanisms including voltage- and receptor-operated membrane channels, and store-operated calcium entry (SOCE) [17, 23, 70-73]. In striated muscle, excitation-contraction coupling is often dependent on membrane depolarization via opening of voltage-dependent $\mathrm{Ca}^{2+}$ channels. However, voltage- dependent $\mathrm{Ca}^{2+}$ channels do not appear to strongly influence membrane depolarization and refilling of internal stores in ASM cells [74] suggesting other mechanisms for $\mathrm{Ca}^{2+}$ entry to maintain ASM contraction. Store depletion-induced $\mathrm{Ca}^{2+}$ entry via store-operated $\mathrm{Ca}^{2+}$ channels ( $\mathrm{SOCs}$ ) is a common mechanism to activate $\mathrm{Ca}^{2+}$ influx via plasma membrane of ASM [75, 76]. The mechanistic link between store depletion and influx involves stromal interacting molecule (STIM) 1 , and its communication with a cell membrane protein or channel (Orai1) [77, 78]. STIM1 is expressed and plays a role in agonist-induced $\mathrm{Ca}^{2+}$ influx in human ASM [76]. STIM1 is a potential $\mathrm{Ca}^{2+}$ sensor in the SR and has a SR luminal $\mathrm{Ca}^{2+}$ binding domain. Upon store emptying, STIM1 relocates and forms clusters adjacent to the plasma membrane. However, the mechanism by which STIM1 is linked to the membrane channel activation remains unclear [76]. Another major route for $\mathrm{Ca}^{2+}$ influx involves calcium release-activated calcium channels (CRAC) that are activated when the $\mathrm{Ca}^{2+}$ content within the SR/ER falls. Originally, SERCA pump activity was considered one of the major determinants of CRAC activities because when SERCA pump activity is decreased, CRAC current develops. Recent studies in T cells indicate that mitochondria also play a key role in the regulation of this $\mathrm{Ca}^{2+}$ influx pathway. Following $\mathrm{Ca}^{2+}$ release from the store (ER), mitochondria rapidly take up calcium, which results in further $\mathrm{Ca}^{2+}$ depletion of the store with concomitant activation of CRAC channels [79-82]. $\mathrm{Ca}^{2+}$ uptake by mitochondria increases the sensitivity of store-operated $\mathrm{Ca}^{2+}$ entry [81]. The 
mechanisms remain unclear, but it appears that mitochondria reduce $\mathrm{Ca}^{2+}$-dependent inactivation of CRAC channels via microtubule-dependent translocation of mitochondria to the plasma membrane $[79,80]$. Inhibiting mitochondrial movement abolishes mitochondrial plasma membrane translocation and reduces sustained $\mathrm{Ca}^{2+}$ signals [79]. The physiological significance of these phenomena is still unclear particularly in ASM cells, but they all support a role for mitochondria in $\mathrm{Ca}^{2+}$ signaling by modulating $\mathrm{Ca}^{2+}$ transport pathways.

\section{Mitochondria in the regulation of ASM proliferation}

Increase of bronchial smooth muscle mass characterized by hyperplasia and hypertrophy of ASM is a key feature of remodeling in asthma. The underlying mechanisms are complicated but mitochondria play an important role. Under pathological conditions, elevation of intracellular $\mathrm{Ca}^{2+}$ levels are associated with subsequent activation of $\mathrm{Ca}^{2+}$-calmodulincalcineurin-NFAT signaling cascade leading to gene expression and increased cell proliferation [83-85]. Nuclear factor of activated T cells (NFATs) are a family of transcription factors that play a central role in the proliferation of a variety of cell types and functions of organ systems. Calcium activates calmodulin and calcineurin, resulting in dephosphorylation and translocation of NFAT from the cytosol to the nucleus, where it functions as the transcription factor to induce gene expression.Interestingly, NFAT translocation is exquisitely sensitive to $\mathrm{Ca}^{2+}$ microdomains near open store-operated CRAC channels [83]. Kinetics linking CRAC channel activation to NFAT nuclear localization indicate that the rate-limiting step in calcium-mediated gene expression is the exit of NFAT from the nucleus (not the sustained calcium elevation in the cytosol). These findings suggest a novel mechanism by which $\mathrm{Ca}^{2+}$-dependent responses can be sustained despite the termination of the initial $\mathrm{Ca}^{2+}$ signal to allow gene expression to continue after the primary stimulus has been removed [83]. In ASM cells, activation of vanilloid transient receptor potential channel (TRPV4) by synthetic and endogenous TRPV4 agonists increase proliferation of ASM cells. Additional studies suggest that NFAT is activated upon stimulation of TRPV4 and this presumably involves colocalization of TRPV4 and calcineurin in calcium microdomains. Translocation of activated NFAT leads to induction of ASM cell proliferation [84]. Recent studies also suggest a role for microRNA miR-143-3p in the regulation of ASM cell proliferation in an NFAT-dependent manner [85]. Levels of miR-143-3p were found to be significantly decreased in ASM cells from asthmatic patients compared to non-asthmatic individuals. As a negative regulator of NFATc1, miR-143-3p overexpression significantly decreased transforming growth factor beta (TGF- $\beta$ )-induced ASM proliferation [85].

While the rise of intracellular $\mathrm{Ca}^{2+}$ concentration in response to agonist stimulation is essential for ASM contraction, restoration of normal basal $\mathrm{Ca}^{2+}$ concentration and preventing long-lasting rise of $\mathrm{Ca}^{2+}$ could be critical for ASM proliferation. Excessive cytoplasmic $\mathrm{Ca}^{2+}$ is taken up into the SR by SERCA or extruded to the extracellular space by plasma membrane $\mathrm{Ca}^{2+}$-ATPase (PMCA) and NCX [86-89]. Recent studies indicate that PMCA is likely involved in the regulation of ASM proliferation via a calcium-dependent mechanism [90]. Inhibiting PMCA decreased the decay rate of the bradykinin-induced $\mathrm{Ca}^{2+}$ transient. This impaired $\mathrm{Ca}^{2+}$ clearance caused sustained elevation of intracellular $\mathrm{Ca}^{2+}$ and ASM proliferation suggesting the role of PMCA in ASM cell proliferation [90]. Like in 
many other cell types, SERCA is the major mechanism in human ASM for replenishing calcium stores. In human ASM cells, SERCA is regulated by calcium/calmodulin-dependent protein kinase II (CaMKII)-related mechanisms and Inflammation maintains intracellular $\mathrm{Ca}^{2+}$ levels by decreasing SERCA expression and attenuating $\mathrm{Ca}^{2+}$ reuptake into SR. Because $\mathrm{Ca}^{2+}$ levels in ASM are increased in asthma, these studies suggest that decreased SERCA expression and function could be the mechanism for the increase in intracellular $\mathrm{Ca}^{2+}[91,92]$. Recent studies also suggest a role for SERCA in the regulation of ASM proliferation and remodeling. Both SERCA2 mRNA and protein levels are reduced in ASM cells of asthmatic patients [93]. The decrease in SERCA2 levels is associated with attenuation of agonist-induced rise of intracellular $\mathrm{Ca}^{2+}$ and a delay in returning to the baseline level of $\mathrm{Ca}^{2+}$. Knocking down SERCA2 by siRNA approaches increased cell spreading and more importantly ASM proliferation [93]. These findings suggest that the decrease in SERCA2 expression may happen during early stage of asthma. This decrease in SERCA2 expression and function decreases $\mathrm{Ca}^{2+}$ reuptake into SR, leading to increased intracellular $\mathrm{Ca}^{2+}$ levels, which may contribute to the ASM phenotypic switch and progression of asthma.

As the key regulator of intracellular calcium, mitochondrial dysfunction contributes to ASM cell proliferation and remodeling. There is increasing evidence that cross talk between mitochondrial calcium buffering and SR calcium homeostasis plays an important role in ASM proliferation. Inflammation and cigarette smoke cause mitochondrial dysfunction which impair the calcium buffering capacity of mitochondria $[94,95]$. The decrease in $\mathrm{Ca}^{2+}$ buffering leads to an increase in intracellular $\mathrm{Ca}^{2+}$ level and presumably ASM proliferation. Mitochondrial dysfunction also increases mitochondrial ROS generation, resulting in ER/SR stress and breaks in $\mathrm{Ca}^{2+}$ homeostasis in ASM. While the majority of the studies involving patients of different disease severity indicated that elevated intracellular calcium concentration contributes to the hyperproliferative phenotype of ASM cells in asthma, disrupted calcium balance changes mitochondrial biogenesis, potentially leading to excessive ASM proliferation. In support of this hypothesis recent studies have demonstrated that ASM cells from asthmatic patients have an increased mitochondrial number and oxygen consumption, indicating increased mitochondrial biogenesis [96]. Furthermore, in severe asthma, altered calcium handling involves phosphorylation of calcium/calmodulindependent protein kinase IV (CaMK-IV) and subsequent activation of peroxisome proliferator-activated receptor $\gamma$ coactivator- $1 a$ (PGC1-a), nuclear respiratory factor-1 (NRF-1) and mitochondrial transcription factor A (mtTFA) [97]. mtTFA is a transcription factor playing a key role in the regulation of mitochondrial DNA replication. These findings further suggest increased biogenesis of mitochondria in asthmatic ASM cells. In addition, mitochondrial dynamics and mitochondrial dynamics-related proteins are closely related to the intracellular $\mathrm{Ca}^{2+}$ levels. Increased intracellular and mitochondrial $\mathrm{Ca}^{2+}$ enhance mitochondrial fission [98] and are associated with changes in the expression of mitochondrial fission and fusion proteins. In fact, mitofusin (Mfn) 2, also called hyperplasia suppressor gene, is implicated not only in mitochondria fusion and tethering of mitochondrial and ER/SR membranes, but also in cell proliferation $[99,100]$. These observations reiterate the hypothesis that mitochondrial mechanisms play a central role in the regulation of ASM cell proliferation in airway diseases. 
Although enhanced airway contractility and airway remodeling are the two main pathological features of asthma, the role of oxygen (hypoxia and hyperoxia) in modulating ASM structure and function of the airway during these processes is not known. Recent studies demonstrate that human fetal ASM cells respond to oxygen in a dose-dependent manner, which could contribute to childhood airway disease [101]. In fetal ASM cells, both acetylcholine and histamine induced calcium mobilization and agonist-induced calcium response was augmented upon exposure to increased oxygen up to $60 \%$. However, exposure of fetal ASM cells to more than $60 \%$ oxygen diminished histamine- and acetylcholineinduced calcium mobilization. Further, fetal ASM showed enhanced proliferation at baseline compared to adult ASM cells. Proliferation of fetal ASM was increased by hyperoxia up to $60 \%$ whereas exposure to more than $60 \%$ oxygen resulted in diminished proliferation coupled with enhanced apoptosis. Interestingly, mitochondrial fusion was increased in response to higher than $60 \%$ of oxygen, supporting a role for fetal ASM mitochondria in not only sensing the oxygen but also assessing the risks of supplemental oxygen in prematurity [101].

\section{Mitochondria in the regulation of ROS-mediated effects in ASM}

ROS regulates many aspects of ASM biology including contraction, proliferation and migration. As in many other cell types, mitochondria are one of the major sites of ROS production in ASM. Electrons leaked from ETC during electron transfer react with oxygen to generate ROS in the form of superoxide $\left(\mathrm{O}_{2}^{-}\right)$. Mitochondrial ROS ( $\mathrm{mtROS}$ ) level is regulated by antioxidant enzymes such as superoxide dismutase and catalase that can eliminate ROS by converting $\mathrm{O}_{2}{ }^{-}$to hydrogen peroxide $\left(\mathrm{H}_{2} \mathrm{O}_{2}\right)$ and ultimately to harmless $\mathrm{H}_{2} \mathrm{O}$. Other major determinants of mtROS are the redox status of ETC, and electrical and chemical gradients [102-104]. However, the mechanism by which electrical/chemical gradients regulate ROS generation is not well understood. Although mtROS can be biologically important in a variety of physiological processes including cell signaling and autophagy, mtROS overproduction is detrimental.

ROS can cause cellular damage and impair ASM contraction [105] (Pan unpublished data). The consequence of ROS on ASM contractility is dependent on the dose, the duration of exposure and the type of species of ROS [105-107]. For example, treating canine distal airway strips or bovine tracheal strips with hydrogen peroxide $\left(10^{-5}-10^{-3} \mathrm{M}\right)$ resulted in ASM contractions that were partially reversed by oxygen radical scavengers, suggesting the contraction is mediated by ROS [106]. In a separate study, it was demonstrated that $\mathrm{H}_{2} \mathrm{O}_{2}$ treatment contracts trachealis muscle in a concentration-dependent manner beginning at 1 $\mathrm{mM}$, which is not attributable to the release of prostaglandins, acetylcholine, or other neurotransmitters. On the contrary, $0.1 \mathrm{mM}$ or more of $\mathrm{H}_{2} \mathrm{O}_{2}$ attenuated the responses to electrical field stimulator, acetylcholine, and $\mathrm{KCl}$ in a concentration-dependent manner in another study [108]. It appears that at high concentrations, $\mathrm{H}_{2} \mathrm{O}_{2}$ affected the responses of ASM by actions on neurotransmission, muscarinic receptors, and downstream components. However, electric field induced-contractile responses of isolated bronchi are enhanced after exposure to $\mathrm{H}_{2} \mathrm{O}_{2}$ in rats [108]. Exposure of rabbits or cats to ROS-generating enzyme systems leads to enhanced contraction to acetylcholine in vitro and in vivo [109, 110]. In addition, ozone and $\mathrm{H}_{2} \mathrm{O}_{2}$ are able to induce increases in airway responsiveness to 
acetylcholine and bradykinin [111, 112]. Interestingly, ROS can decrease function and number of $\beta$-adrenergic receptors present in lung tissue (presumably decreasing the ability of ASM to relax), which can be reversed by superoxide dismutase [113-117]. In asthmatic ASM in vivo and in primary ASM culture, the generation of ROS is increased with an associated increase in the expression of adenine dinucleotide phosphate oxidase type 4 (NOX4) enzyme, resulting in oxidative stress in ASM cells. This increase in oxidative stress is correlated to the degree of airflow obstruction and airway hyperresponsiveness (AHR) $[118,119]$. More importantly, the antioxidant mitoubiquinone mesylate (MitoQ) reverses ozone-induced AHR and inflammation, suggesting a key role for mitochondrial ROS in the development of these pathological conditions [11]. Increased ROS generation damages cellular DNA, carbohydrates, proteins and lipids leading to increased inflammatory responses [120, 121]. Furthermore, increased oxidative stress damages mitochondria such as in patients with COPD in which mitochondrial dysfunction drives inflammation and ASM remodeling [11]. Mice exposed to oxidative stress develop lung inflammation and AHR, similar to that observed in patients with COPD, which is associated with decreased mitochondrial membrane potential and increased mitochondria ROS generation. All these studies clearly demonstrate the role of mitochondria in the regulation of oxidative stress and ROS generation in airway resident cells such as ASM cells leading to increased airway inflammation, remodeling and AHR (Figure 3).

Exposure of cultured ASM cells to mitogenic stimuli switches ASM cells from a contractile, hypoproliferative to a proliferative, hypocontractile phenotype, as indicated by changes in molecular phenotypic markers [122, 123]. Many studies suggest that ROS can regulate cell proliferation [124-126]. Alternatively, in other cell types such as in tumors, although proliferating phenotypes are associated with low levels of mtROS, the role for mtROS in ASM cell proliferation is not well characterized. Cell proliferation and migration begin with stimulation of cell surface receptors and the transduction of the external signals to a series of cellular responses. ERK and PI3K activation appear to be the dominant signal transduction pathways for RTK-, GPCR-, or cytokine-stimulated ASM growth [127]. Accumulating evidence indicates that ROS are important modulators of mitogenic signaling via several different mechanisms. First, ROS can function as the second messenger in signal transduction [128]. Secondly, ROS regulates cell cycle progression by directly modulating the phosphorylation and ubiquitination of cell cycle-related enzymes [128]. Finally, ROS can activate growth factor receptors in the absence of the growth factor ligands leading to cell proliferation [129]. Antioxidants such as $\mathrm{N}$-acetylcysteine, catalase and probucol significantly reduce ASM proliferation induced by fetal bovine serum or platelet-derived growth factor suggesting that ROS is involved in mitogenic stimulation of ASM cell [130].

In the pulmonary artery, smooth muscle cells switch from OXPHOS to glycolysis and activation of mitochondrial fission protein dynamin-like protein 1 (DLP1) is associated with the hyperproliferative phenotype in smooth muscle cells in pulmonary arterial hypertension [131]. However, little is known about the role of metabolic shift in ASM cells during airway inflammatory conditions.

Increased ROS generation increases mitochondria fragmentation and mitochondrial dysfunction. When this happens, damaged mitochondria are removed by autophagy. 
Autophagy is an evolutionarily conserved process to maintain the cellular energy balance [132-134]. It is mediated by a special organelle called an autophagosome. Autophagy consists of several sequential steps, including sequestration, degradation, and amino acid generation. During autophagy proteolytic degradation of cytosolic components at the lysosomes remove damaged organelles and degrade cellular proteins. The cellular building blocks such as amino acids generated during autophagy by proteolytic cleavage are recycled [135]. Autophagy happens in most of the cells at the basal level and is enhanced in response to stress situations such as nutrient depletion, during which autophagy generates the constituents required for the cell survival. Recent studies have demonstrated that autophagy plays a role in a variety of physiological and pathological processes besides adaptation to starvation such as development, aging, cancer, and muscle disorders [135]. Furthermore, autophagic removal of damaged proteins and organelles including mitochondria, endoplasmic reticulum, and peroxisomes, serves as an important quality control mechanism for cell survival [136]. The regulation of autophagy in mammals is very complicated and involves multiple signaling pathways [137-139]. Our studies demonstrated that chronic exposure of human ASM cells to bitter taste receptor (TAS2R) agonists up-regulates Bnip3, a Bcl-2 family protein that is critical in mitochondrial autophagy. The increase in Bnip3 levels is concomitant with increased mitochondrial ROS, DLP1-mediated mitochondrial fragmentation and ASM cell death, which can be rescued by autophagy inhibitors [140] These findings demonstrated that TAS2R agonist-mediated cell death in human ASM cells involves autophagy, and Bnip3 is a mitochondrial target for the antimitogenic effect of TAS2R agonists.

Multiple lines of evidence suggest that in response to stimuli such as growth factors, cytokines, chemokines and particulate matter mitochondria undergo structural changes characterized by fusion and fission. This process is an obligatory critical step in the initiation of mitochondria-mediated cellular processes. The balance between mitochondrial fusion and fission (fragmentation) is important for the formation and maintenance of mitochondrial filamentous networks in human ASM cells, which respond dynamically to changes in the extracellular and intracellular environment [141, 142]. Cellular organization of mitochondria is vital for cellular homeostasis and orchestration of physiological functions of mitochondria as well as other organelles. Coupling of the mitochondrial membrane to the ER/SR membrane plays an important role in cell bioenergetics, cell fate determination and proliferation [3].

Under homeostatic physiological conditions in ASM, the balance between ATP demand and production is maintained by the coupling between $\left[\mathrm{Ca}^{2+}\right]_{\text {cyto }}$ and $\left[\mathrm{Ca}^{2+}\right]_{\mathrm{m}}$. Mfn 2 is important for this dynamic interaction between mitochondria and the ER/SR (mitochondriaassociated ER/SR membrane, MAM) [99]. Mfn 1 and 2 are important for fusion whereas fragmentation is regulated by DLP1 [3]. Recent evidence has shown a decrease in Mfn2 levels concurrent with an increase in Drp1 protein expression in patients with mild asthma [95]. This change in protein expression was shown to coincide with increased mitochondrial fragmentation and human ASM proliferation under asthmatic conditions [3]. A consequence of asthma is a disruption of cellular energy dynamics. The presence of inflammatory cytokines such as TNFa and IL-13 in asthmatic human ASM cells leads to an increase in ATP demand, ER/SR stress due to uncoupling of these organelles from mitochondria and the 
shift of human ASM cells into a synthetic state, which is characterized by increased mitochondrial fragmentation and cellular proliferation [3].

Defects in mitochondrial function have been identified as the cause for onset of smoking related diseases like COPD [143]. Cigarette smoke introduces over 5000 chemical compounds, which contain ROS such as $\mathrm{H}_{2} \mathrm{O}_{2}, \mathrm{O}_{2}{ }^{-}$, and hydroxyl free radicals. Smokers have also been shown to have elevated levels of endogenous ROS production in addition to exogenous sources of ROS in cigarette smoke. Direct evidence for cigarette smoke-induced structural and functional changes in ASM came from a recent study that demonstrated cigarette smoke-induced mitochondrial fragmentation and decreased oxygen consumption rate in ASM cells [95].

Mitochondrial DNA (mtDNA) is separate and unique from nuclear DNA. Many mtDNA encoded proteins are involved in the repair of oxidative damage of cellular proteins from ROS and reactive nitrogen species (RNS), which are byproducts of oxidative phosphorylation. ${ }^{13}$ Proteins involved in the maintenance of mtDNA, such as superoxide dismutases, are encoded by nuclear genes. Disruption of the dynamic interaction and crosstalk between mitochondria and the SR can lead to defects in mtDNA repair mechanisms, elevated levels of $\left[\mathrm{Ca}^{2+}\right]_{\mathrm{cyto}}$ and increased ROS production $[3,144]$. Furthermore, elevated levels of ROS can overwhelm cellular antioxidant responses and increase the activation of transcription factors involved in inflammation such as nuclear factor kappa-light-chain-enhancer of activated B cells (NF- $\kappa B$ ) and NRF-2 ${ }^{132}$. These observations suggest that ablation of the interplay between mitochondria and the nucleus plays a key role in the disruption of mitochondrial energetics, cell fate determination and pathogenesis of many human disorders including asthma, COPD, neurodegenerative diseases and cancer ${ }^{132}$.

\section{Mitochondria in hypoxia-mediated effects on ASM}

ASM cells are dependent upon the diffusion of oxygen across the basement membrane or microvessels within the connective tissue of the airway wall [145]. Asthmatic lung tissue is susceptible to hypoxia due to the thickening of the basement membrane $[145,146]$. Increased levels of ROS during hypoxic stress following bronchoconstriction can lead to expression of transcription factors belonging to the hypoxia inducible factor (HIF) family [145]. HIF-1 regulates ATP production by suppressing the ETC and driving mitochondria to switch from OXPHOS to $\beta$-oxidation of fatty acids for energy during hypoxia [144]. Under normal conditions, HIF1- $a$ is hydroxylated at two proline residues and targeted for proteasomal degradation via ubiquitinylation by Von Hippel-Lindau protein (VHL) and elongin C (Eloc) [145]. Under hypoxic conditions such as those witnessed in asthmatic ASM, HIF1-a hydroxylation is impaired, allowing HIF1-a to form a heterodimeric complex with HIF1- $\beta$ and bind to hypoxia response elements in the nucleus [145]. The currently known gene targets downstream of these response elements are known to play a role in angiogenesis, erythropoiesis, ventilation, glycolysis and autophagy [145] (Figure 4).

Consistently elevated HIF-1 levels are known to contribute to hyperresponsiveness in asthmatic ASM [147]. ASM proliferation, and the subsequent rise in number of 
mitochondria, increases the oxygen demand necessary to fuel ATP production. Oxygen deprivation of ASM due to thickening of the basement membrane leads to HIF-mediated angiogenesis of microvessels within the submucosa of the airway wall $[145,146]$. The airway submucosa of asthmatic patients has been observed to have higher levels of angiogenic factors such as VEGF, EGF and angiopoietin in response to pro-inflammatory cytokines like IL-13 or TGF- $\beta$ [148]. However, the structural integrity in the endothelium of these newly formed microvessels is often poor, as similarly observed in the hypoxic environment of tumors [149]. Degradation of tight junctions within the endothelium of these vessels allows excess fluid and immune cells to leak into the submucosa of the airway wall, resulting in edema and localized inflammation [145]. Mitochondria are pivotal in the regulation of multiple pathogenic processes emanating from the physiological response of mitochondria to hypoxia and energy demand of the cell.

Recent literature suggests that platelets may also play a key role in inflammation and airway remodeling due to increased platelet reactivity in asthmatic individuals [150]. Immunologic and nonimmunologic depletion of platelets in ovalbumin (OVA)-sensitized mice resulted in significant attenuation of ASM thickening and extracellular matrix deposition [150]. Thrombi have been shown to release growth factors that facilitate the smooth muscle growth. Furthermore, chronically challenged OVA-mice suffered from airway remodeling in the absence of eosinophils, suggesting that air remodeling may persist even following the attenuation of an inflammatory immune response [150]. Platelets are able to directly interact with eosinophils that buildup in airway tissue following hypoxic angiogenesis, further reinforcing the immune-mediated inflammatory response [149]. Although mitochondrial number and morphology remained unchanged in platelets of asthmatics, expression of citric acid cycle enzymes aconitase, succinate dehydrogenase and citrate synthase are upregulated in platelet mitochondria in asthmatics compared to healthy individuals under hypoxic conditions [149]. This dynamic difference in mitochondrial function allows for increased ATP and ROS production despite restricted oxygen intake in individuals with asthma. Despite these findings, the mechanisms by which immunological cell-derived ATP, growth factor and cytokine production affect ASM proliferation remain to be elucidated [150]. Further investigation is also necessary to determine the importance of platelets and immune cell crosstalk on ASM mitochondrial energy dynamics and proliferation in the pathogenesis diseases such as asthma and COPD.

Taken together studies to date suggest that healthy mitochondria are essential for normal structure and function of the airway cells, which is central to lung physiology. Mitochondrial dysfunction associated with aberrant mitochondrial dynamics and excessive mitochondrial ROS generation can be used as markers, as well as targets in the pathogenesis of lung diseases. One such example is that the administration of mitochondrial targeted antioxidant, MitoTEMPO (2-(2,2,6,6-Tetramethylpiperidin-1-oxyl-4-ylamino)-2-oxoethyl) triphenylphosphonium chloride) in mouse attenuated neonatal hyperoxia-induced lung injury [151]. Similarly, MitoTEMPO significantly deceased mitochondrial ROS generation, TGF$\beta$, and collagen deposition in OVA-challenged mice [152]. In a mouse model of COPD, both a mitochondrial antioxidant MitoQ, and an inhibitor of DLP1 which blocks mitochondrial fission, reversed the adverse effect of cigarette smoking on mitophagy [153]. However, the direct evidence connecting various lung diseases and mitochondria abnormalities is missing. 
Whether mitochondrial changes are cause or effect of lung diseases needs to be established. Additional studies on targeting drugs precisely to mitochondria may provide novel therapeutic strategies for lung diseases.

\section{Summary}

Chronic inflammation in the lungs leads to progressive structural and functional changes in airway cells including ASM cells resulting in bronchoconstriction. The cellular and molecular pathogenesis of airway diseases includes the progression of ASM from a mature, contractile phenotype into a synthetic and hyperproliferative phenotype. The importance of changes in calcium mobilization, calcium sensitivity and cellular bioenergetics in asthmatic ASM has been well established in the literature. However, there is ever increasing evidence implicating the role of mitochondria in the regulation of these cellular dynamics.

Inflammation, hypoxia, cigarette smoke are major causes of mitochondrial dysfunction including mitochondrial fragmentation, uncoupling from the SR and change in mitochondrial membrane potential all of which lead to increased ROS production and a greater amount of stress in ASM cells. These phenomena play significant roles in ASM cell proliferation (fragmentation) and calcium hypersensitivity (mitochondrial uncoupling).

A deeper understanding of the importance of mitochondria in asthma and COPD open new avenues for drug discovery. Mitochondria-specific antioxidants such as MitoQ and MitoTEMPO have been shown to be effective in reversing mitochondrial dysfunction, suppressing ROS and preventing oxidative damage in in vitro studies and animal models [154]. Despite the need to further elucidate the specific role of mitochondrial dysfunction in the pathology of AHR, remodeling and inflammation, mitochondrial-specific therapeutics represent a potentially effective option to eventually be used in place of or in tandem with the current standard of care.

\section{Acknowledgements}

The studies in DAD lab are funded by the National Institute of Health (HL087560). The authors declare that they have no conflicts of interest with the contents of this article.

\section{References}

[1]. Owens GK. Regulation of differentiation of vascular smooth muscle cells. Physiol Rev 1995;75(3):487-517. [PubMed: 7624392]

[2]. Stegemann JP, Hong H, Nerem RM. Mechanical, biochemical, and extracellular matrix effects on vascular smooth muscle cell phenotype. J Appl Physiol (1985) 2005;98(6):2321-2327. [PubMed: 15894540]

[3]. Delmotte P, Sieck GC. Interaction between endoplasmic/sarcoplasmic reticulum stress (ER/SR stress), mitochondrial signaling and $\mathrm{Ca}(2+)$ regulation in airway smooth muscle (ASM). Can $\mathrm{J}$ Physiol Pharmacol 2015;93(2):97-110. [PubMed: 25506723]

[4]. Voet D VJ. Biochemistry 3rd ed: New York: John Wiley \& Sons, Inc p. 615; 2004.

[5]. Berg JM TJ, Stryer L. Biochemistry 5th ed: New York: W H Freeman; 2002.

[6]. Alberts B JA, Lewis J, et al. Molecular Biology of the Cell 4th ed: New York: Garland Science; 2002.

[7]. Hatefi Y The mitochondrial electron transport and oxidative phosphorylation system. Annu Rev Biochem 1985;54:1015-1069. [PubMed: 2862839] 
[8]. Blachly-Dyson E, Forte M. VDAC channels. IUBMB Life 2001;52(3-5):113-118. [PubMed: 11798022]

[9]. Palty R, Hershfinkel M, Sekler I. Molecular identity and functional properties of the mitochondrial $\mathrm{Na} / \mathrm{Ca} 2+$ exchanger. J Biol Chem 2012;287(38):31650-31657. [PubMed: 22822063]

[10]. Palty R, Silverman WF, Hershfinkel M, Caporale T, Sensi SL, Parnis J, Nolte C, Fishman D, Shoshan-Barmatz V, Herrmann S, Khananshvili D, Sekler I. NCLX is an essential component of mitochondrial Na+/Ca2+ exchange. Proc Natl Acad Sci U S A 2010;107(1):436-441. [PubMed: 20018762]

[11]. Wiegman CH, Michaeloudes C, Haji G, Narang P, Clarke CJ, Russell KE, Bao W, Pavlidis S, Barnes PJ, Kanerva J, Bittner A, Rao N, Murphy MP, Kirkham PA, Chung KF, Adcock IM, Copdmap. Oxidative stress-induced mitochondrial dysfunction drives inflammation and airway smooth muscle remodeling in patients with chronic obstructive pulmonary disease. J Allergy Clin Immunol 2015;136(3):769-780. [PubMed: 25828268]

[12]. Reddy PH. Mitochondrial Dysfunction and Oxidative Stress in Asthma: Implications for Mitochondria-Targeted Antioxidant Therapeutics. Pharmaceuticals (Basel) 2011;4(3):429-456. [PubMed: 21461182]

[13]. Mabalirajan U, Ghosh B. Mitochondrial dysfunction in metabolic syndrome and asthma. J Allergy (Cairo) 2013;2013:340476. [PubMed: 23840225]

[14]. Deshpande DA, Wang WC, McIlmoyle EL, Robinett KS, Schillinger RM, An SS, Sham JS, Liggett SB. Bitter taste receptors on airway smooth muscle bronchodilate by localized calcium signaling and reverse obstruction. Nat Med 2010;16(11):1299-1304. [PubMed: 20972434]

[15]. Saxena H, Deshpande DA, Tiegs BC, Yan H, Battafarano RJ, Burrows WM, Damera G, Panettieri RA, Dubose TD, Jr., An SS, Penn RB. The GPCR OGR1 (GPR68) mediates diverse signalling and contraction of airway smooth muscle in response to small reductions in extracellular $\mathrm{pH}$. $\mathrm{Br} \mathrm{J}$ Pharmacol 2012;166(3):981-990. [PubMed: 22145625]

[16]. Mizuta K, Xu D, Pan Y, Comas G, Sonett JR, Zhang Y, Panettieri RA, Jr., Yang J, Emala CW, Sr. GABAA receptors are expressed and facilitate relaxation in airway smooth muscle. Am J Physiol Lung Cell Mol Physiol 2008;294(6):L1206-1216. [PubMed: 18408071]

[17]. Murray RK, Kotlikoff MI. Receptor-activated calcium influx in human airway smooth muscle cells. J Physiol 1991;435:123-144. [PubMed: 1663158]

[18]. Shieh CC, Petrini MF, Dwyer TM, Farley JM. Concentration-dependence of acetylcholineinduced changes in calcium and tension in swine trachealis. J Pharmacol Exp Ther 1991;256(1): 141-148. [PubMed: 1988654]

[19]. Sims SM, Jiao Y, Zheng ZG. Intracellular calcium stores in isolated tracheal smooth muscle cells. Am J Physiol 1996;271(2 Pt 1):L300-309. [PubMed: 8770069]

[20]. Pelaia G, Renda T, Gallelli L, Vatrella A, Busceti MT, Agati S, Caputi M, Cazzola M, Maselli R, Marsico SA. Molecular mechanisms underlying airway smooth muscle contraction and proliferation: implications for asthma. Respir Med 2008;102(8):1173-1181. [PubMed: 18579364]

[21]. Baron CB, Cunningham M, Strauss JF, 3rd, Coburn RF. Pharmacomechanical coupling in smooth muscle may involve phosphatidylinositol metabolism. Proc Natl Acad Sci U S A 1984;81(21): 6899-6903. [PubMed: 6593735]

[22]. Murray RK, Bennett CF, Fluharty SJ, Kotlikoff MI. Mechanism of phorbol ester inhibition of histamine-induced IP3 formation in cultured airway smooth muscle. Am J Physiol 1989;257(4 Pt 1):L209-216. [PubMed: 2508487]

[23]. Murray RK, Fleischmann BK, Kotlikoff MI. Receptor-activated Ca influx in human airway smooth muscle: use of Ca imaging and perforated patch-clamp techniques. Am J Physiol 1993;264(2 Pt 1):C485-490. [PubMed: 8383435]

[24]. Santo-Domingo J, Demaurex N. Calcium uptake mechanisms of mitochondria. Biochim Biophys Acta 2010;1797(6-7):907-912. [PubMed: 20079335]

[25]. Rizzuto R, Brini M, Murgia M, Pozzan T. Microdomains with high Ca2+ close to IP3-sensitive channels that are sensed by neighboring mitochondria. Science 1993;262(5134):744-747. [PubMed: 8235595] 
[26]. Griffiths EJ, Rutter GA. Mitochondrial calcium as a key regulator of mitochondrial ATP production in mammalian cells. Biochim Biophys Acta 2009;1787(11):1324-1333. [PubMed: 19366607]

[27]. Delmotte P, Zavaletta VA, Thompson MA, Prakash YS, Sieck GC. TNFalpha decreases mitochondrial movement in human airway smooth muscle. Am J Physiol Lung Cell Mol Physiol 2017;313(1):L166-L176. [PubMed: 28473328]

[28]. Rizzuto R, Pinton P, Carrington W, Fay FS, Fogarty KE, Lifshitz LM, Tuft RA, Pozzan T. Close contacts with the endoplasmic reticulum as determinants of mitochondrial $\mathrm{Ca} 2+$ responses. Science 1998;280(5370):1763-1766. [PubMed: 9624056]

[29]. Drummond RM, Tuft RA. Release of $\mathrm{Ca} 2+$ from the sarcoplasmic reticulum increases mitochondrial $[\mathrm{Ca} 2+]$ in rat pulmonary artery smooth muscle cells. J Physiol 1999;516 (Pt 1): 139-147. [PubMed: 10066929]

[30]. Chalmers S, McCarron JG. The mitochondrial membrane potential and $\mathrm{Ca} 2+$ oscillations in smooth muscle. J Cell Sci 2008;121(Pt 1):75-85. [PubMed: 18073239]

[31]. Narayanan D, Xi Q, Pfeffer LM, Jaggar JH. Mitochondria control functional CaV1.2 expression in smooth muscle cells of cerebral arteries. Circ Res 2010;107(5):631-641. [PubMed: 20616314]

[32]. Sward K, Dreja K, Lindqvist A, Persson E, Hellstrand P. Influence of mitochondrial inhibition on global and local [Ca(2+)](I) in rat tail artery. Circ Res 2002;90(7):792-799. [PubMed: 11964372]

[33]. Szado T, Kuo KH, Bernard-Helary K, Poburko D, Lee CH, Seow C, Ruegg UT, van Breemen C. Agonist-induced mitochondrial Ca2+ transients in smooth muscle. FASEB J 2003;17(1):28-37. [PubMed: 12522109]

[34]. Olson ML, Chalmers S, McCarron JG. Mitochondrial organization and Ca2+ uptake. Biochem Soc Trans 2012;40(1):158-167. [PubMed: 22260683]

[35]. McCarron JG, Muir TC. Mitochondrial regulation of the cytosolic Ca2+ concentration and the InsP3-sensitive Ca2+ store in guinea-pig colonic smooth muscle. J Physiol 1999;516 (Pt 1):149161. [PubMed: 10066930]

[36]. Fornaro L, Vasile E, Masi G, Loupakis F, Caponi S, Ginocchi L, Falcone A. Capecitabine after gastrectomy for advanced gastric cancer: have we got the patient right? Ann Oncol 2010;21(1): 181.

[37]. De Stefani D, Raffaello A, Teardo E, Szabo I, Rizzuto R. A forty-kilodalton protein of the inner membrane is the mitochondrial calcium uniporter. Nature 2011;476(7360):336-340. [PubMed: 21685888]

[38]. Baughman JM, Perocchi F, Girgis HS, Plovanich M, Belcher-Timme CA, Sancak Y, Bao XR, Strittmatter L, Goldberger O, Bogorad RL, Koteliansky V, Mootha VK. Integrative genomics identifies MCU as an essential component of the mitochondrial calcium uniporter. Nature 2011;476(7360):341-345. [PubMed: 21685886]

[39]. Raffaello A, De Stefani D, Rizzuto R. The mitochondrial Ca(2+) uniporter. Cell Calcium 2012;52(1):16-21. [PubMed: 22672876]

[40]. Gunter TE, Pfeiffer DR. Mechanisms by which mitochondria transport calcium. Am J Physiol 1990;258(5 Pt 1):C755-786. [PubMed: 2185657]

[41]. Gunter TE, Gunter KK, Sheu SS, Gavin CE. Mitochondrial calcium transport: physiological and pathological relevance. Am J Physiol 1994;267(2 Pt 1):C313-339. [PubMed: 8074170]

[42]. Gunter TE, Sheu SS. Characteristics and possible functions of mitochondrial $\mathrm{Ca}(2+)$ transport mechanisms. Biochim Biophys Acta 2009;1787(11):1291-1308. [PubMed: 19161975]

[43]. Rizzuto R, Pinton P, Brini M, Chiesa A, Filippin L, Pozzan T. Mitochondria as biosensors of calcium microdomains. Cell Calcium 1999;26(5):193-199. [PubMed: 10643557]

[44]. Rizzuto R, Duchen MR, Pozzan T. Flirting in little space: the ER/mitochondria Ca2+ liaison. Sci STKE 2004;2004(215):re1. [PubMed: 14722345]

[45]. Rizzuto R, Marchi S, Bonora M, Aguiari P, Bononi A, De Stefani D, Giorgi C, Leo S, Rimessi A, Siviero R, Zecchini E, Pinton P. Ca(2+) transfer from the ER to mitochondria: when, how and why. Biochim Biophys Acta 2009;1787(11):1342-1351. [PubMed: 19341702]

[46]. Rizzuto R, Pozzan T. Microdomains of intracellular Ca2+: molecular determinants and functional consequences. Physiol Rev 2006;86(1):369-408. [PubMed: 16371601] 
[47]. Pizzo P, Drago I, Filadi R, Pozzan T. Mitochondrial Ca(2)(+) homeostasis: mechanism, role, and tissue specificities. Pflugers Arch 2012;464(1):3-17. [PubMed: 22706634]

[48]. Roux E, Marhl M. Role of sarcoplasmic reticulum and mitochondria in Ca2+ removal in airway myocytes. Biophys J 2004;86(4):2583-2595. [PubMed: 15041694]

[49]. Babcock DF, Herrington J, Goodwin PC, Park YB, Hille B. Mitochondrial participation in the intracellular Ca2+ network. J Cell Biol 1997;136(4):833-844. [PubMed: 9049249]

[50]. Duchen MR. Ca(2+)-dependent changes in the mitochondrial energetics in single dissociated mouse sensory neurons. Biochem J 1992;283 (Pt 1):41-50. [PubMed: 1373604]

[51]. Friel DD, Tsien RW. An FCCP-sensitive Ca2+ store in bullfrog sympathetic neurons and its participation in stimulus-evoked changes in [Ca2+]i. J Neurosci 1994;14(7):4007-4024. [PubMed: 8027759]

[52]. Thayer SA, Miller RJ. Regulation of the intracellular free calcium concentration in single rat dorsal root ganglion neurones in vitro. J Physiol 1990;425:85-115. [PubMed: 2213592]

[53]. White RJ, Reynolds IJ. Mitochondria accumulate Ca2+ following intense glutamate stimulation of cultured rat forebrain neurones. J Physiol 1997;498 (Pt 1):31-47. [PubMed: 9023766]

[54]. Prakash YS, Pabelick CM, Kannan MS, Sieck GC. Spatial and temporal aspects of ACh-induced [Ca2+]i oscillations in porcine tracheal smooth muscle. Cell Calcium 2000;27(3):153-162. [PubMed: 11007128]

[55]. Liu X, Farley JM. Acetylcholine-induced chloride current oscillations in swine tracheal smooth muscle cells. J Pharmacol Exp Ther 1996;276(1):178-186. [PubMed: 8558428]

[56]. Liu X, Farley JM. Acetylcholine-induced Ca++-dependent chloride current oscillations are mediated by inositol 1,4,5-trisphosphate in tracheal myocytes. J Pharmacol Exp Ther 1996;277(2):796-804. [PubMed: 8627561]

[57]. White TA, Kannan MS, Walseth TF. Intracellular calcium signaling through the cADPR pathway is agonist specific in porcine airway smooth muscle. FASEB J 2003;17(3):482-484. [PubMed: 12551848]

[58]. Prakash YS, Kannan MS, Sieck GC. Regulation of intracellular calcium oscillations in porcine tracheal smooth muscle cells. Am J Physiol 1997;272(3 Pt 1):C966-975. [PubMed: 9124533]

[59]. Kannan MS, Prakash YS, Brenner T, Mickelson JR, Sieck GC. Role of ryanodine receptor channels in Ca2+ oscillations of porcine tracheal smooth muscle. Am J Physiol 1997;272(4 Pt 1):L659-664. [PubMed: 9142939]

[60]. Dai JM, Kuo KH, Leo JM, van Breemen C, Lee CH. Mechanism of ACh-induced asynchronous calcium waves and tonic contraction in porcine tracheal muscle bundle. Am J Physiol Lung Cell Mol Physiol 2006;290(3):L459-469. [PubMed: 16214818]

[61]. Dai JM, Kuo KH, Leo JM, Pare PD, van Breemen C, Lee CH. Acetylcholine-induced asynchronous calcium waves in intact human bronchial muscle bundle. Am J Respir Cell Mol Biol 2007;36(5):600-608. [PubMed: 17170384]

[62]. Du W, Stiber JA, Rosenberg PB, Meissner G, Eu JP. Ryanodine receptors in muscarinic receptormediated bronchoconstriction. J Biol Chem 2005;280(28):26287-26294. [PubMed: 15894801]

[63]. Deshpande DA, White TA, Dogan S, Walseth TF, Panettieri RA, Kannan MS. CD38/cyclic ADPribose signaling: role in the regulation of calcium homeostasis in airway smooth muscle. Am J Physiol Lung Cell Mol Physiol 2005;288(5):L773-788. [PubMed: 15821018]

[64]. Rizzuto R, Simpson AW, Brini M, Pozzan T. Rapid changes of mitochondrial Ca2+ revealed by specifically targeted recombinant aequorin. Nature 1992;358(6384):325-327. [PubMed: 1322496]

[65]. Rizzuto R, Bastianutto C, Brini M, Murgia M, Pozzan T. Mitochondrial Ca2+ homeostasis in intact cells. J Cell Biol 1994;126(5):1183-1194. [PubMed: 8063855]

[66]. Hoth M, Fanger CM, Lewis RS. Mitochondrial regulation of store-operated calcium signaling in T lymphocytes. J Cell Biol 1997;137(3):633-648. [PubMed: 9151670]

[67]. Jouaville LS, Ichas F, Holmuhamedov EL, Camacho P, Lechleiter JD. Synchronization of calcium waves by mitochondrial substrates in Xenopus laevis oocytes. Nature 1995;377(6548): 438-441. [PubMed: 7566122] 
[68]. Chalmers S, McCarron JG. Inhibition of mitochondrial calcium uptake rather than efflux impedes calcium release by inositol-1,4,5-trisphosphate-sensitive receptors. Cell Calcium 2009;46(2): 107-113. [PubMed: 19577805]

[69]. Liu X, Farley JM. Depletion and refilling of acetylcholine- and caffeine-sensitive Ca++ stores in tracheal myocytes. J Pharmacol Exp Ther 1996;277(2):789-795. [PubMed: 8627560]

[70]. Ay B, Prakash YS, Pabelick CM, Sieck GC. Store-operated Ca2+ entry in porcine airway smooth muscle. Am J Physiol Lung Cell Mol Physiol 2004;286(5):L909-917. [PubMed: 14617522]

[71]. Worley JF, 3rd, Kotlikoff MI. Dihydropyridine-sensitive single calcium channels in airway smooth muscle cells. Am J Physiol 1990;259(6 Pt 1):L468-480. [PubMed: 1701979]

[72]. Putney JW, Jr. A model for receptor-regulated calcium entry. Cell Calcium 1986;7(1):1-12. [PubMed: 2420465]

[73]. Takemura H, Putney JW, Jr. Capacitative calcium entry in parotid acinar cells. Biochem J 1989;258(2):409-412. [PubMed: 2650680]

[74]. Janssen LJ. Ionic mechanisms and $\mathrm{Ca}(2+)$ regulation in airway smooth muscle contraction: do the data contradict dogma? Am J Physiol Lung Cell Mol Physiol 2002;282(6):L1161-1178. [PubMed: 12003770]

[75]. Parekh AB, Putney JW, Jr. Store-operated calcium channels. Physiol Rev 2005;85(2):757-810. [PubMed: 15788710]

[76]. Peel SE, Liu B, Hall IP. A key role for STIM1 in store operated calcium channel activation in airway smooth muscle. Respir Res 2006;7:119. [PubMed: 16987424]

[77]. Smyth JT, Dehaven WI, Jones BF, Mercer JC, Trebak M, Vazquez G, Putney JW, Jr. Emerging perspectives in store-operated Ca2+ entry: roles of Orai, Stim and TRP. Biochim Biophys Acta 2006;1763(11):1147-1160. [PubMed: 17034882]

[78]. Parekh AB. A CRAC current tango. Nat Cell Biol 2006;8(7):655-656. [PubMed: 16820776]

[79]. Quintana A, Schwarz EC, Schwindling C, Lipp P, Kaestner L, Hoth M. Sustained activity of calcium release-activated calcium channels requires translocation of mitochondria to the plasma membrane. J Biol Chem 2006;281(52):40302-40309. [PubMed: 17056596]

[80]. Parekh AB. Mitochondrial regulation of store-operated CRAC channels. Cell Calcium 2008;44(1):6-13. [PubMed: 18243304]

[81]. Parekh AB. Store-operated Ca2+ entry: dynamic interplay between endoplasmic reticulum, mitochondria and plasma membrane. J Physiol 2003;547(Pt 2):333-348. [PubMed: 12576497]

[82]. Chen J, Sanderson MJ. Store-operated calcium entry is required for sustained contraction and $\mathrm{Ca}(2+)$ oscillations of airway smooth muscle. J Physiol 2017;595(10):3203-3218. [PubMed: 27396568]

[83]. Kar P, Nelson C, Parekh AB. Selective activation of the transcription factor NFAT1 by calcium microdomains near Ca2+ release-activated Ca2+ (CRAC) channels. J Biol Chem 2011;286(17): 14795-14803. [PubMed: 21325277]

[84]. Zhao L, Sullivan MN, Chase M, Gonzales AL, Earley S. Calcineurin/nuclear factor of activated T cells-coupled vanilliod transient receptor potential channel $4 \mathrm{ca} 2+$ sparklets stimulate airway smooth muscle cell proliferation. Am J Respir Cell Mol Biol 2014;50(6):1064-1075. [PubMed: 24392954]

[85]. Cheng W, Yan K, Xie LY, Chen F, Yu HC, Huang YX, Dang CX. MiR-143-3p controls TGFbeta1-induced cell proliferation and extracellular matrix production in airway smooth muscle via negative regulation of the nuclear factor of activated T cells 1. Mol Immunol 2016;78:133-139. [PubMed: 27639060]

[86]. Bublitz M, Musgaard M, Poulsen H, Thogersen L, Olesen C, Schiott B, Morth JP, Moller JV, Nissen P. Ion pathways in the sarcoplasmic reticulum Ca2+-ATPase. J Biol Chem 2013;288(15): 10759-10765. [PubMed: 23400778]

[87]. Brini M, Carafoli E. The plasma membrane $\mathrm{Ca}(2)+$ ATPase and the plasma membrane sodium calcium exchanger cooperate in the regulation of cell calcium. Cold Spring Harb Perspect Biol 2011;3(2).

[88]. Sathish V, Delmotte PF, Thompson MA, Pabelick CM, Sieck GC, Prakash YS. Sodium-calcium exchange in intracellular calcium handling of human airway smooth muscle. PLoS One 2011;6(8):e23662. [PubMed: 21858195] 
[89]. Rahman M, Inman M, Kiss L, Janssen LJ. Reverse-mode NCX current in mouse airway smooth muscle: $\mathrm{Na}(+)$ and voltage dependence, contributions to $\mathrm{Ca}(2+)$ influx and contraction, and altered expression in a model of allergen-induced hyperresponsiveness. Acta Physiol (Oxf) 2012;205(2):279-291. [PubMed: 22212361]

[90]. Chen YF, Cao J, Zhong JN, Chen X, Cheng M, Yang J, Gao YD. Plasma membrane Ca2+ATPase regulates $\mathrm{Ca} 2+$ signaling and the proliferation of airway smooth muscle cells. Eur $\mathbf{J}$ Pharmacol 2014;740:733-741. [PubMed: 24912144]

[91]. Sathish V, Thompson MA, Bailey JP, Pabelick CM, Prakash YS, Sieck GC. Effect of proinflammatory cytokines on regulation of sarcoplasmic reticulum $\mathrm{Ca} 2+$ reuptake in human airway smooth muscle. Am J Physiol Lung Cell Mol Physiol 2009;297(1):L26-34. [PubMed: 19395670]

[92]. Prakash YS, Sathish V, Thompson MA, Pabelick CM, Sieck GC. Asthma and sarcoplasmic reticulum Ca2+ reuptake in airway smooth muscle. Am J Physiol Lung Cell Mol Physiol 2009;297(4):L794. [PubMed: 19783641]

[93]. Mahn K, Hirst SJ, Ying S, Holt MR, Lavender P, Ojo OO, Siew L, Simcock DE, McVicker CG, Kanabar V, Snetkov VA, O'Connor BJ, Karner C, Cousins DJ, Macedo P, Chung KF, Corrigan CJ, Ward JP, Lee TH. Diminished sarco/endoplasmic reticulum Ca2+ ATPase (SERCA) expression contributes to airway remodelling in bronchial asthma. Proc Natl Acad Sci U S A 2009;106(26):10775-10780. [PubMed: 19541629]

[94]. Delmotte P, Yang B, Thompson MA, Pabelick CM, Prakash YS, Sieck GC. Inflammation alters regional mitochondrial $\mathrm{Ca}(2)+$ in human airway smooth muscle cells. Am J Physiol Cell Physiol 2012;303(3):C244-256. [PubMed: 22673614]

[95]. Aravamudan B, Kiel A, Freeman M, Delmotte P, Thompson M, Vassallo R, Sieck GC, Pabelick CM, Prakash YS. Cigarette smoke-induced mitochondrial fragmentation and dysfunction in human airway smooth muscle. Am J Physiol Lung Cell Mol Physiol 2014;306(9):L840-854. [PubMed: 24610934]

[96]. Girodet PO, Ozier A, Bara I, Tunon de Lara JM, Marthan R, Berger P. Airway remodeling in asthma: new mechanisms and potential for pharmacological intervention. Pharmacol Ther 2011;130(3):325-337. [PubMed: 21334378]

[97]. Trian T, Benard G, Begueret H, Rossignol R, Girodet PO, Ghosh D, Ousova O, Vernejoux JM, Marthan R, Tunon-de-Lara JM, Berger P. Bronchial smooth muscle remodeling involves calciumdependent enhanced mitochondrial biogenesis in asthma. J Exp Med 2007;204(13):3173-3181. [PubMed: 18056286]

[98]. Bravo-Sagua R, Parra V, Lopez-Crisosto C, Diaz P, Quest AF, Lavandero S. Calcium Transport and Signaling in Mitochondria. Compr Physiol 2017;7(2):623-634. [PubMed: 28333383]

[99]. de Brito OM, Scorrano L. Mitofusin 2 tethers endoplasmic reticulum to mitochondria. Nature 2008;456(7222):605-610. [PubMed: 19052620]

[100]. Eura Y, Ishihara N, Yokota S, Mihara K. Two mitofusin proteins, mammalian homologues of FZO, with distinct functions are both required for mitochondrial fusion. J Biochem 2003;134(3): 333-344. [PubMed: 14561718]

[101]. Hartman WR, Smelter DF, Sathish V, Karass M, Kim S, Aravamudan B, Thompson MA, Amrani Y, Pandya HC, Martin RJ, Prakash YS, Pabelick CM. Oxygen dose responsiveness of human fetal airway smooth muscle cells. Am J Physiol Lung Cell Mol Physiol 2012;303(8):L711-719. [PubMed: 22923637]

[102]. Selivanov VA, Zeak JA, Roca J, Cascante M, Trucco M, Votyakova TV. The role of external and matrix $\mathrm{pH}$ in mitochondrial reactive oxygen species generation. J Biol Chem 2008;283(43): 29292-29300. [PubMed: 18687689]

[103]. Dzbek J, Korzeniewski B. Control over the contribution of the mitochondrial membrane potential (DeltaPsi) and proton gradient (DeltapH) to the protonmotive force (Deltap). In silico studies. J Biol Chem 2008;283(48):33232-33239. [PubMed: 18694940]

[104]. Lambert AJ, Brand MD. Superoxide production by NADH:ubiquinone oxidoreductase (complex I) depends on the $\mathrm{pH}$ gradient across the mitochondrial inner membrane. Biochem J 2004;382(Pt 2):511-517. 
[105]. Olszewski MA, Robinson NE, Yu MF, Derksen FJ. Effects of hydrogen peroxide on isolated trachealis muscle of horses. Am J Vet Res 1995;56(11):1479-1485. [PubMed: 8585660]

[106]. Stewart RM, Weir EK, Montgomery MR, Niewoehner DE. Hydrogen peroxide contracts airway smooth muscle: a possible endogenous mechanism. Respir Physiol 1981;45(3):333-342. [PubMed: 7330488]

[107]. Matyas S, Pucovsky V, Bauer V. Effects of various reactive oxygen species on the guinea pig trachea and its epithelium. Jpn J Pharmacol 2002;88(3):270-278. [PubMed: 11949881]

[108]. Szarek JL, Schmidt NL. Hydrogen peroxide-induced potentiation of contractile responses in isolated rat airways. Am J Physiol 1990;258(4 Pt 1):L232-237. [PubMed: 2333980]

[109]. Katsumata U, Miura M, Ichinose M, Kimura K, Takahashi T, Inoue H, Takishima T. Oxygen radicals produce airway constriction and hyperresponsiveness in anesthetized cats. Am Rev Respir Dis 1990;141(5 Pt 1):1158-1161. [PubMed: 2131784]

[110]. Prasad K, Gupta JB. Influence of hydroxyl radical on rabbit airway smooth muscle chronically exposed to H2O2 in vivo. Am J Physiol 1993;264(6 Pt 1):L566-574. [PubMed: 8392812]

[111]. Asano T, Hattori T, Tada T, Kajikuri J, Kamiya T, Saitoh M, Yamada Y, Itoh M, Itoh T. Role of the epithelium in opposing $\mathrm{H}(2) \mathrm{O}(2)$-induced modulation of acetylcholine-induced contractions in rabbit intrapulmonary bronchiole. Br J Pharmacol 2001;132(6):1271-1280. [PubMed: 11250878]

[112]. Tsukagoshi H, Haddad EB, Sun J, Barnes PJ, Chung KF. Ozone-induced airway hyperresponsiveness: role of superoxide anions, NEP, and BK receptors. J Appl Physiol (1985) 1995;78(3):1015-1022. [PubMed: 7775293]

[113]. Kramer K, Rademaker B, Rozendal WH, Timmerman H, Bast A. Influence of lipid peroxidation on beta-adrenoceptors. FEBS Lett 1986;198(1):80-84. [PubMed: 3007208]

[114]. Nijkamp FP, Henricks PA. Receptors in airway disease. Beta-adrenoceptors in lung inflammation. Am Rev Respir Dis 1990;141(3 Pt 2):S145-150. [PubMed: 2155563]

[115]. Engels F, Oosting RS, Nijkamp FP. Pulmonary macrophages induce deterioration of guinea-pig tracheal beta-adrenergic function through release of oxygen radicals. Eur J Pharmacol 1985;111(1):143-144. [PubMed: 2990941]

[116]. Engels F, Oosting RS, Nijkamp FP. Dual effects of Haemophilus influenzae on guinea pig tracheal beta-adrenergic receptor function: involvement of oxygen-centered radicals from pulmonary macrophages. J Pharmacol Exp Ther 1987;241(3):994-999. [PubMed: 3037075]

[117]. Ikuta N, Sugiyama S, Takagi K, Satake T, Ozawa T. Implication of oxygen radicals on airway hyperresponsiveness after ovalbumin challenge in guinea pigs. Am Rev Respir Dis 1992;145(3): 561-565. [PubMed: 1312312]

[118]. Sutcliffe A, Hollins F, Gomez E, Saunders R, Doe C, Cooke M, Challiss RA, Brightling CE. Increased nicotinamide adenine dinucleotide phosphate oxidase 4 expression mediates intrinsic airway smooth muscle hypercontractility in asthma. Am J Respir Crit Care Med 2012;185(3): 267-274. [PubMed: 22108207]

[119]. Loukides S, Bouros D, Papatheodorou G, Panagou P, Siafakas NM. The relationships among hydrogen peroxide in expired breath condensate, airway inflammation, and asthma severity. Chest 2002;121(2):338-346. [PubMed: 11834641]

[120]. Henricks PA, Nijkamp FP. Reactive oxygen species as mediators in asthma. Pulm Pharmacol Ther 2001;14(6):409-420. [PubMed: 11782121]

[121]. Suski JM, Lebiedzinska M, Bonora M, Pinton P, Duszynski J, Wieckowski MR. Relation between mitochondrial membrane potential and ROS formation. Methods Mol Biol 2012;810:183-205. [PubMed: 22057568]

[122]. Hirst SJ, Twort CH, Lee TH. Differential effects of extracellular matrix proteins on human airway smooth muscle cell proliferation and phenotype. Am J Respir Cell Mol Biol 2000;23(3): 335-344. [PubMed: 10970824]

[123]. Halayko AJ, Tran T, Gosens R. Phenotype and functional plasticity of airway smooth muscle: role of caveolae and caveolins. Proc Am Thorac Soc 2008;5(1):80-88. [PubMed: 18094089]

[124]. Burdon RH, Alliangana D, Gill V. Hydrogen peroxide and the proliferation of BHK-21 cells. Free Radic Res 1995;23(5):471-486. [PubMed: 7581830] 
[125]. Carreras MC, Poderoso JJ. Mitochondrial nitric oxide in the signaling of cell integrated responses. Am J Physiol Cell Physiol 2007;292(5):C1569-1580. [PubMed: 17496232]

[126]. Carreras MC, Converso DP, Lorenti AS, Barbich M, Levisman DM, Jaitovich A, Antico Arciuch VG, Galli S, Poderoso JJ. Mitochondrial nitric oxide synthase drives redox signals for proliferation and quiescence in rat liver development. Hepatology 2004;40(1):157-166. [PubMed: 15239099]

[127]. Ammit AJ, Panettieri RA, Jr. Invited review: the circle of life: cell cycle regulation in airway smooth muscle. J Appl Physiol (1985) 2001;91(3):1431-1437. [PubMed: 11509545]

[128]. Boonstra J, Post JA. Molecular events associated with reactive oxygen species and cell cycle progression in mammalian cells. Gene 2004;337:1-13. [PubMed: 15276197]

[129]. Inoguchi T, Sonta T, Tsubouchi H, Etoh T, Kakimoto M, Sonoda N, Sato N, Sekiguchi N, Kobayashi K, Sumimoto H, Utsumi H, Nawata H. Protein kinase C-dependent increase in reactive oxygen species (ROS) production in vascular tissues of diabetes: role of vascular NAD(P)H oxidase. J Am Soc Nephrol 2003;14(8 Suppl 3):S227-232. [PubMed: 12874436]

[130]. Brar SS, Kennedy TP, Whorton AR, Murphy TM, Chitano P, Hoidal JR. Requirement for reactive oxygen species in serum-induced and platelet-derived growth factor-induced growth of airway smooth muscle. J Biol Chem 1999;274(28):20017-20026. [PubMed: 10391952]

[131]. Marsboom G, Toth PT, Ryan JJ, Hong Z, Wu X, Fang YH, Thenappan T, Piao L, Zhang HJ, Pogoriler J, Chen Y, Morrow E, Weir EK, Rehman J, Archer SL. Dynamin-related protein 1mediated mitochondrial mitotic fission permits hyperproliferation of vascular smooth muscle cells and offers a novel therapeutic target in pulmonary hypertension. Circ Res 2012;110(11): 1484-1497. [PubMed: 22511751]

[132]. Levine B, Klionsky DJ. Development by self-digestion: molecular mechanisms and biological functions of autophagy. Dev Cell 2004;6(4):463-477. [PubMed: 15068787]

[133]. Lippai M, Szatmari Z. Autophagy-from molecular mechanisms to clinical relevance. Cell Biol Toxicol 2017;33(2):145-168. [PubMed: 27957648]

[134]. Papandreou ME, Tavernarakis N. Autophagy and the endo/exosomal pathways in health and disease. Biotechnol J 2017;12(1).

[135]. Mizushima N Autophagy: process and function. Genes Dev 2007;21(22):2861-2873. [PubMed: 18006683]

[136]. Glick D, Barth S, Macleod KF. Autophagy: cellular and molecular mechanisms. J Pathol 2010;221(1):3-12. [PubMed: 20225336]

[137]. Byfield MP, Murray JT, Backer JM. hVps34 is a nutrient-regulated lipid kinase required for activation of p70 S6 kinase. J Biol Chem 2005;280(38):33076-33082. [PubMed: 16049009]

[138]. Codogno P, Meijer AJ. Autophagy and signaling: their role in cell survival and cell death. Cell Death Differ 2005;12 Suppl 2:1509-1518. [PubMed: 16247498]

[139]. Nobukuni T, Joaquin M, Roccio M, Dann SG, Kim SY, Gulati P, Byfield MP, Backer JM, Natt F, Bos JL, Zwartkruis FJ, Thomas G. Amino acids mediate mTOR/raptor signaling through activation of class 3 phosphatidylinositol 3OH-kinase. Proc Natl Acad Sci U S A 2005;102(40): 14238-14243. [PubMed: 16176982]

[140]. Pan S, Sharma P, Shah SD, Deshpande DA. Bitter taste receptor agonists alter mitochondrial function and induce autophagy in airway smooth muscle cells. Am J Physiol Lung Cell Mol Physiol 2017;313(1):L154-L165. [PubMed: 28450286]

[141]. Liesa M, Palacin M, Zorzano A. Mitochondrial dynamics in mammalian health and disease. Physiol Rev 2009;89(3):799-845. [PubMed: 19584314]

[142]. Youle RJ, van der Bliek AM. Mitochondrial fission, fusion, and stress. Science 2012;337(6098): 1062-1065. [PubMed: 22936770]

[143]. Nam HS, Izumchenko E, Dasgupta S, Hoque MO. Mitochondria in chronic obstructive pulmonary disease and lung cancer: where are we now? Biomark Med 2017;11(6):475-489. [PubMed: 28598223]

[144]. Saki M, Prakash A. DNA damage related crosstalk between the nucleus and mitochondria. Free Radic Biol Med 2017;107:216-227. [PubMed: 27915046]

[145]. Keglowich LF, Borger P. The Three A's in Asthma - Airway Smooth Muscle, Airway Remodeling \& Angiogenesis. Open Respir Med J 2015;9:70-80. [PubMed: 26106455] 
[146]. Cox G, Miller JD, McWilliams A, Fitzgerald JM, Lam S. Bronchial thermoplasty for asthma. Am J Respir Crit Care Med 2006;173(9):965-969. [PubMed: 16456145]

[147]. Crotty Alexander LE, Akong-Moore K, Feldstein S, Johansson P, Nguyen A, McEachern EK, Nicatia S, Cowburn AS, Olson J, Cho JY, Isaacs H, Jr., Johnson RS, Broide DH, Nizet V Myeloid cell HIF-1alpha regulates asthma airway resistance and eosinophil function. J Mol Med (Berl) 2013;91(5):637-644. [PubMed: 23250618]

[148]. Simcock DE, Kanabar V, Clarke GW, Mahn K, Karner C, O’Connor BJ, Lee TH, Hirst SJ. Induction of angiogenesis by airway smooth muscle from patients with asthma. Am J Respir Crit Care Med 2008;178(5):460-468. [PubMed: 18556625]

[149]. Michael JV, Wurtzel JGT, Mao GF, Rao AK, Kolpakov MA, Sabri A, Hoffman NE, Rajan S, Tomar D, Madesh M, Nieman MT, Yu J, Edelstein LC, Rowley JW, Weyrich AS, Goldfinger LE. Platelet microparticles infiltrating solid tumors transfer miRNAs that suppress tumor growth. Blood 2017;130(5):567-580. [PubMed: 28500171]

[150]. Pitchford SC, Riffo-Vasquez Y, Sousa A, Momi S, Gresele P, Spina D, Page CP. Platelets are necessary for airway wall remodeling in a murine model of chronic allergic inflammation. Blood 2004;103(2):639-647. [PubMed: 14504080]

[151]. Datta A, Kim GA, Taylor JM, Gugino SF, Farrow KN, Schumacker PT, Berkelhamer SK. Mouse lung development and NOX1 induction during hyperoxia are developmentally regulated and mitochondrial ROS dependent. Am J Physiol Lung Cell Mol Physiol 2015;309(4):L369-377. [PubMed: 26092998]

[152]. Jaffer OA, Carter AB, Sanders PN, Dibbern ME, Winters CJ, Murthy S, Ryan AJ, Rokita AG, Prasad AM, Zabner J, Kline JN, Grumbach IM, Anderson ME. Mitochondrial-targeted antioxidant therapy decreases transforming growth factor-beta-mediated Collagen production in a murine asthma model. Am J Respir Cell Mol Biol 2015;52(1):106-115. [PubMed: 24988374]

[153]. Mizumura K, Cloonan SM, Nakahira K, Bhashyam AR, Cervo M, Kitada T, Glass K, Owen CA, Mahmood A, Washko GR, Hashimoto S, Ryter SW, Choi AM. Mitophagy-dependent necroptosis contributes to the pathogenesis of COPD. J Clin Invest 2014;124(9):3987-4003. [PubMed: 25083992]

[154]. Prakash YS, Pabelick CM, Sieck GC. Mitochondrial Dysfunction in Airway Disease. Chest 2017;152(3):618-626. [PubMed: 28336486] 


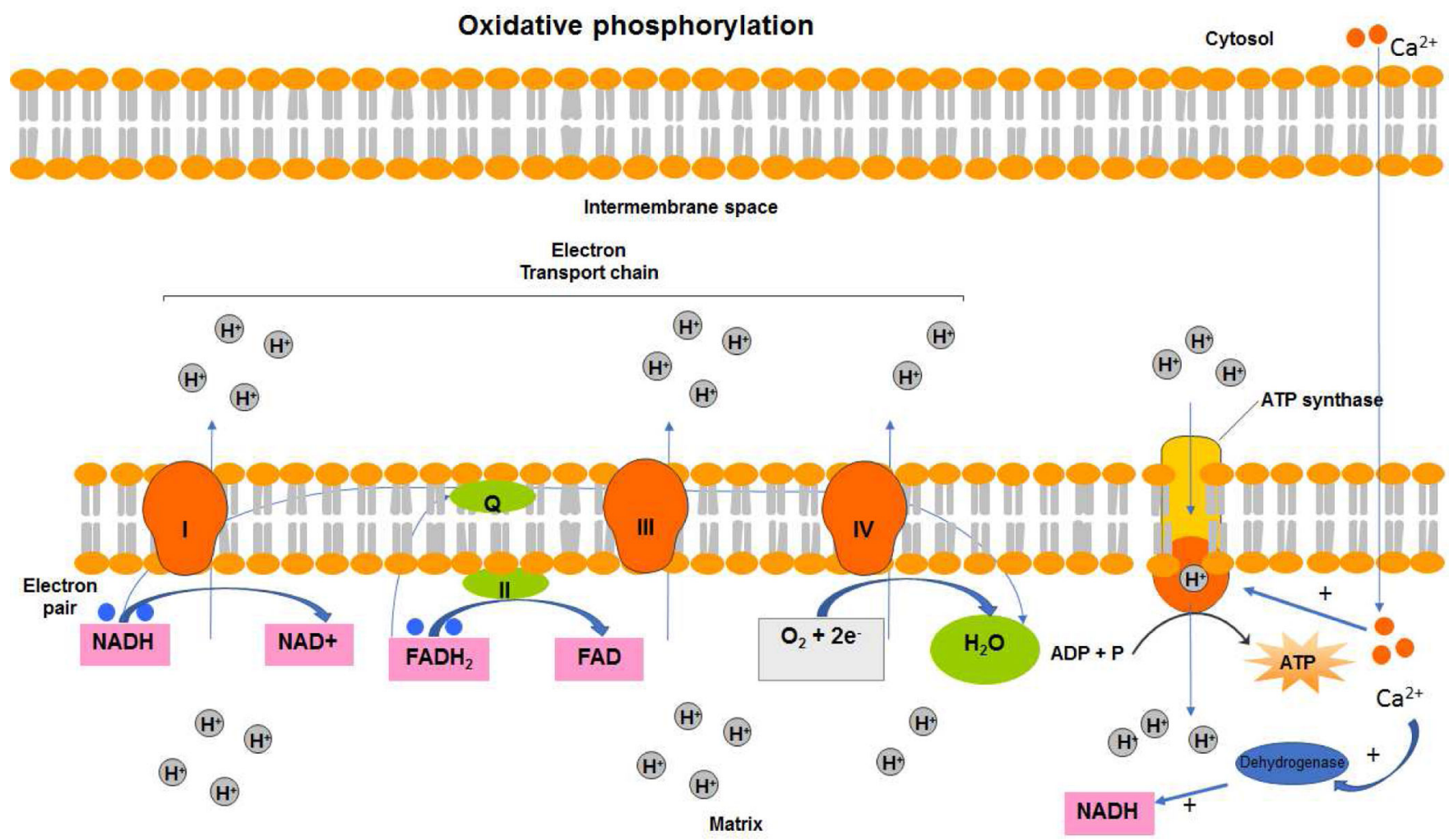

Figure 1: Oxidative phosphorylation.

Mitochondria are responsible for energy production through the process of cellular respiration. The reduction of each complex in the electron transport chain allows for protons to be pumped into the intermembrane space. The buildup of protons in its space eventually creates a concentration gradient known as the proton motive force. The influx of protons back into the mitochondrial matrix through the proton pump, F1F0 ATP synthase, drives the conversion of ADP and inorganic phosphate into ATP, which is an important source of energy for smooth muscle contraction. Activation of multiple mitochondrial enzymes is dependent upon calcium concentration in the mitochondria. Uptake of calcium from cytosol into mitochondrial matrix positively regulate ATP synthesis. 


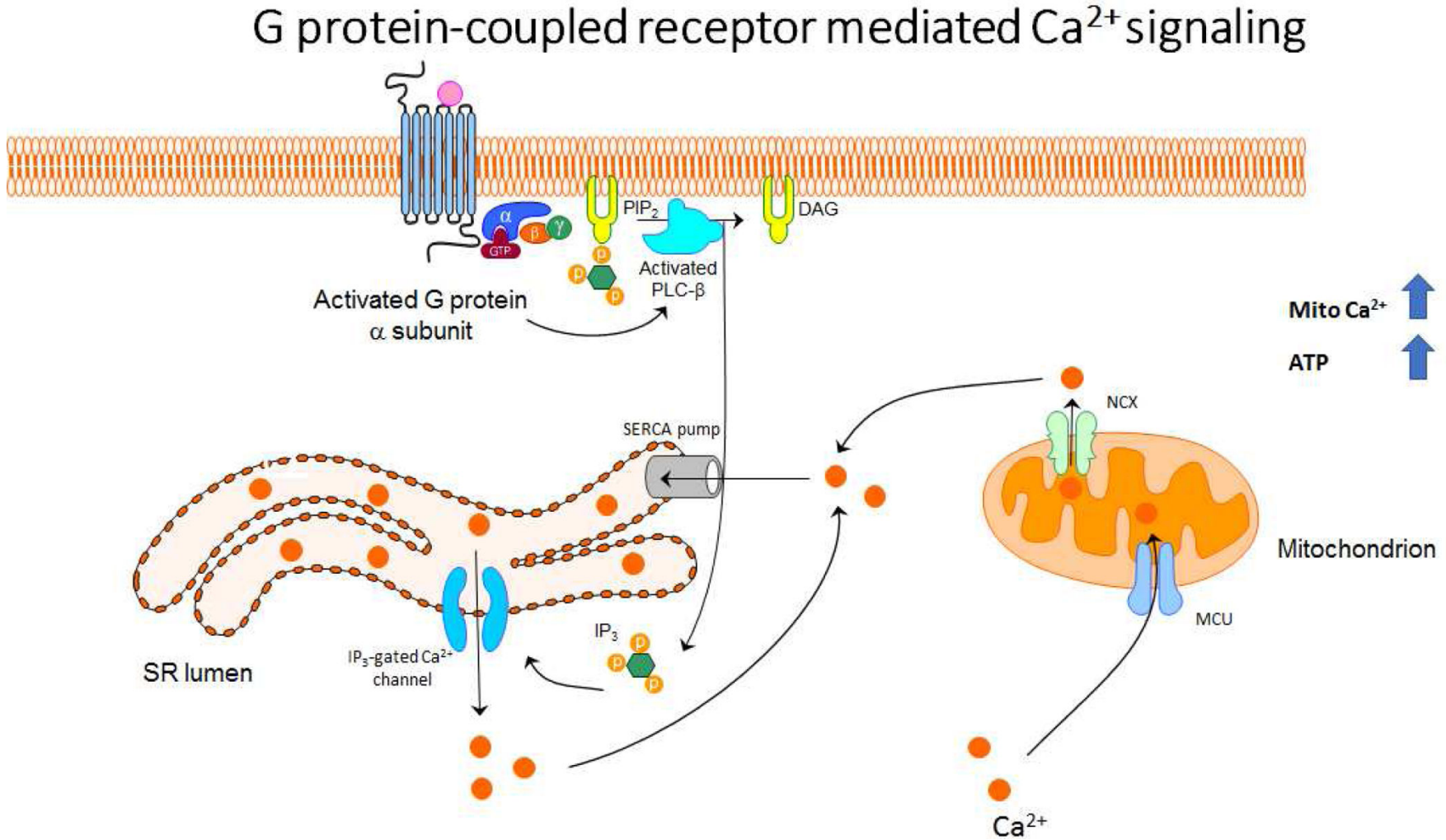

Figure 2: G-protein mediated $\mathrm{Ca}^{2+}$ mobilization.

ASM contraction and relaxation are dependent on changes in cytosolic and mitochondrial calcium. GPCR stimulation and subsequent $\mathrm{G}$ protein activation leads to the activation of PLC- $\beta$. PIP2 is cleaved by PLC- $\beta$ into $\mathrm{IP}_{3}$ and DAG. $\mathrm{IP}_{3}$ binds to $\mathrm{IP}_{3}$-gated $\mathrm{Ca}^{2+}$ channels on the SERCA membrane, causing these channels to open and allow $\mathrm{Ca}^{2+}$ to be released into the cytosol. Mitochondria which are in close proximity to the SR are able to uptake $\mathrm{Ca}^{2+}$ through the MCU, where it can be used by calcium-dependent dehydrogenases in the TCA cycle. Transient mitochondrial calcium fluxes thus lead to the increases in ATP production necessary for both temporary and prolonged ASM contraction. 


\section{Effects of ROS/RNS on mitochondrial function}

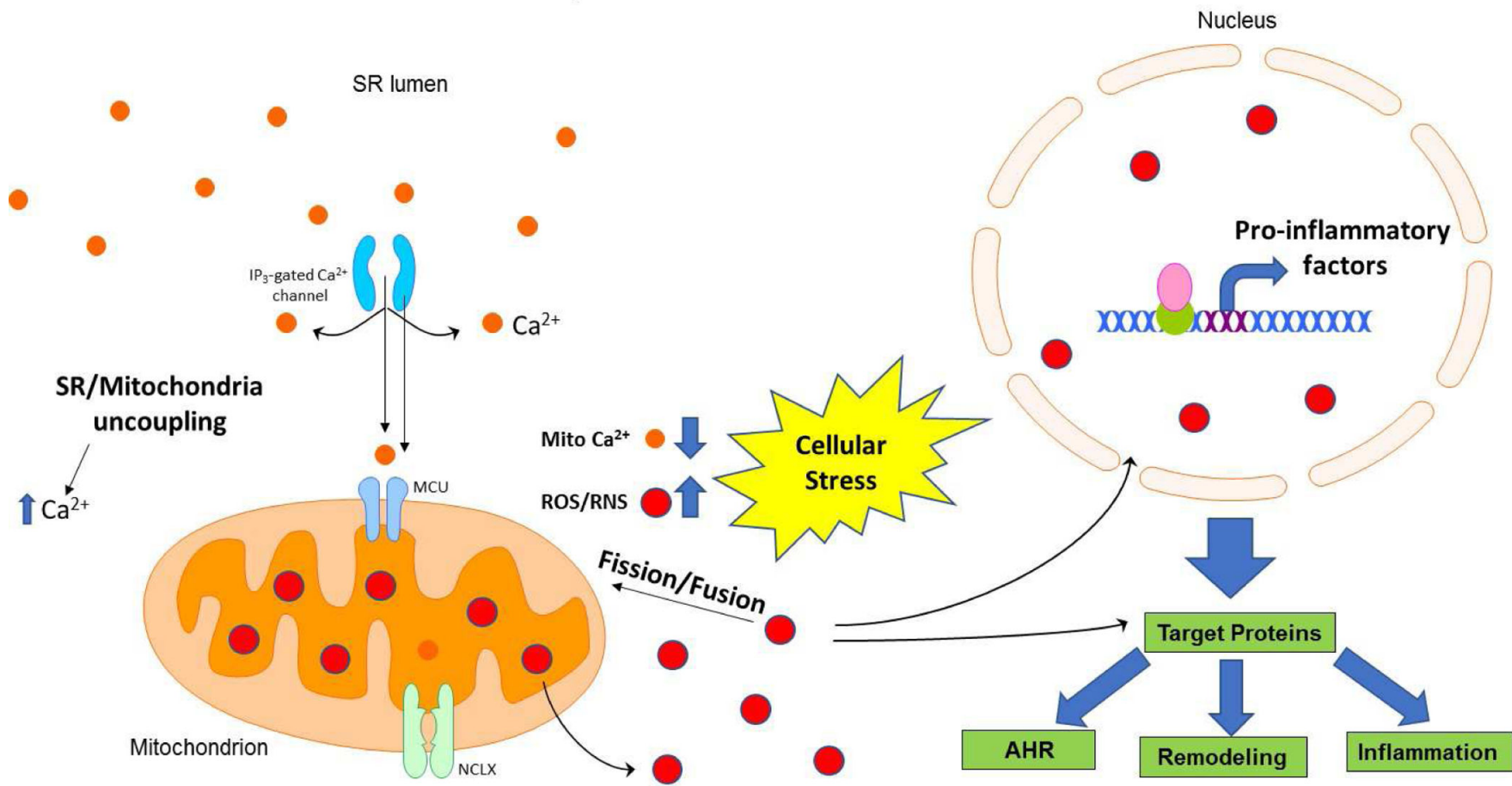

Figure 3: Role of ROS/RNS in mitochondrial dysfunction.

ASM contraction and relaxation are dependent on changes in cytosolic and mitochondrial calcium. Uncoupling of mitochondria from the ER/SR membrane leads to reduced mitochondrial $\mathrm{Ca}^{2+}$ flux, stress-related increases in ROS/RNS and reduced degradation of ROS. Increased ROS/RNS act as a second messenger or chemically modulate the functional ability of ASM proteins and results in increased airway inflammation, airway hyperresponsiveness (AHR) and ASM remodeling. 


\section{Normoxia}
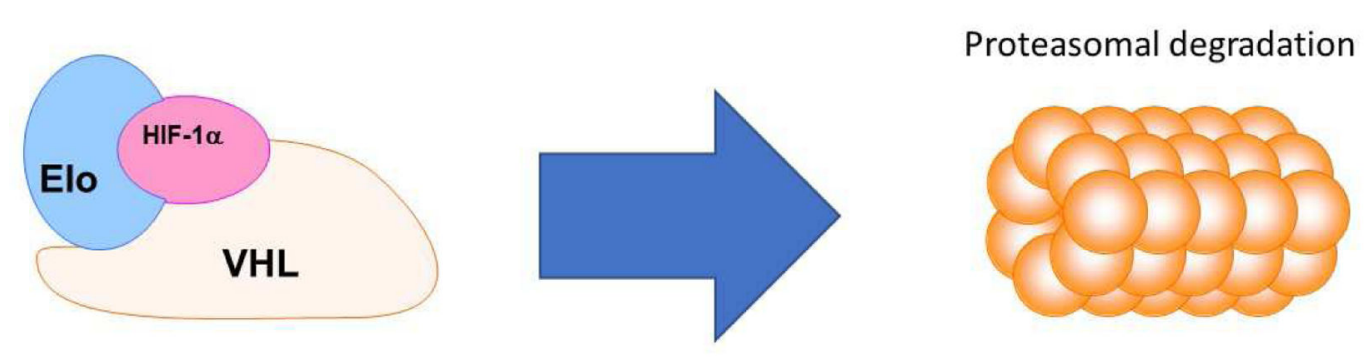

\section{Hypoxia}
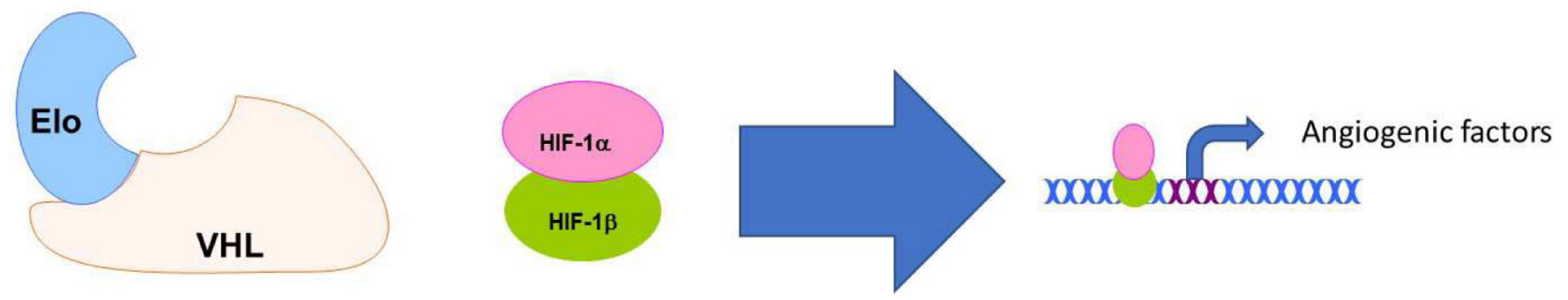

Figure 4: Hypoxia and airway smooth muscle remodeling.

Under non-hypoxic conditions, HIF-1a is bound in a complex with VHL and Elo,

hydroxylated at two proline residues and targeted for proteasomal degradation via E3 ligasemediated ubiquitinylation. However, chronically inflamed lung tissue is susceptible to oxygen deprivation due to thickening of the basement membrane. Hypoxia allows unbound HIF-1a to form a heterodimer with HIF- $\beta$, translocate into the nucleus and binds to hypoxia response elements. Upregulation of these response elements plays a major role in angiogenesis in the extracellular matrix of asthmatic lung tissue. 